\title{
Evidence for transform motion along the South Balearic margin and implications for the kinematics of opening of the Algerian basin
}

\author{
OLIVIER DRIUSSI ${ }^{1}$, ANNE BRIAIS ${ }^{1}$ and AGNÈs MAILLARD ${ }^{1}$
}

Keywords. - South Balearic margin, Algerian basin, Seismic reflexion profiles, Gravity models, Magnetic anomalies, Kinematics, Transform margin.

Abstract. - Two major types of kinematic models have been proposed to explain the opening of the western Mediterranean basins (Liguro-Provençal and Algerian basins, and Valencia trough). In one type of models, all continental blocks bounding the basins drift to the southeast, driven by the rollback of the Tethys subduction slab. In the other type of models, the Alboran domain drifts to the southwest, implying a westward rollback of the broken subducting slab and a NE-SW opening of the Algerian basin. In most models, however, the structure of the Balearic promontory was not taken into account, despite its key location at the boundary of the three major basins. We used the interpretation of a large seismic database coupled to gravity and magnetic anomaly analyses to characterize the nature and structure of the South Balearic margin. The constraints brought by the new analyses allow us to suggest a new scenario for the opening of the Algerian basin.

Seismic profiles show that the South Balearic margin is composed of four segments with different morphologies and crustal structures. Two segments, the Mazarron and the Emile Baudot escarpments, are characterized by steep scarps and sharp crustal thinning. Two other segments, the South Ibiza and South Menorca margins, have a smoother bathymetry and crustal thinning. We interpret the former in terms of transform margins, and the latter as divergent margins. The distribution of faults on the passive margin segments suggests that they have recorded at least two phases of deformation. A first phase of opening, probably in a NW-SE direction, affected the south Balearic margin, and possibly created some oceanic floor. The existence of the transform margin segments and the prominent NW-SE orientation of the magnetic lineations in the eastern Algerian basin suggest that most of this basin opened in a NE-SW direction, in different oceanic corridors. The two eastern corridors formed by the southwestward drift of the Kabylies. The western corridor, bounded by the transform segments of the South Balearic margin and the Algerian margin, results from the southwestward drift of the Alboran domain, as suggested by previous studies.

\section{Evidences d'un mouvement transformant le long de la marge Sud-Baléares et implications pour la cinématique d'ouverture du Bassin algérien}

\begin{abstract}
Mots-clés. - Marge Sud-Baléares, Bassin algérien, Profils sismiques, Modèles gravimétriques, Anomalies magnétiques, Cinématique, Marges transformantes.

Résumé. - Deux grands types de modèles cinématiques ont été proposés pour expliquer l'ouverture des bassins de la Méditerranée occidentale (bassins Liguro-Provençal et Algérien et fossé de Valence). Dans un type de modèles, tous les blocs continentaux limitant les bassins dérivent vers le sud-est, tirés par le retrait de la subduction de la plaque téthysienne. Dans l'autre type de modèles, le domaine d'Alboran dérive vers le sud-ouest, impliquant un retrait vers l'ouest de la subduction d'une partie de la plaque téthysienne déchirée. Dans la plupart de ces modèles, cependant, le promontoire Baléares n'est pas pris en compte, et ce, malgré sa position clé à la frontière des bassins majeurs. Nous avons utilisé l'interprétation d'une large base de données sismiques couplée à une analyse des anomalies gravimétriques et magnétiques pour caractériser la nature et la structure de la marge Sud-Baléares. Les contraintes apportées par les nouvelles analyses nous permettent de proposer un nouveau scénario pour l'ouverture du Bassin algérien.

La sismique réflexion montre que la marge Sud-Baléares est composée de quatre segments qui diffèrent en termes de morphologie et de structure. Deux segments, les escarpements de Mazarron et d'Emile Baudot, sont caractérisés par des escarpements abrupts ainsi que par un rapide amincissement crustal. Les deux autres, les marges au sud d'Ibiza et de Minorque, montrent une bathymétrie moins abrupte et un amincissement crustal plus progressif. Nous interprétons les deux premiers segments comme des marges transformantes et les deux derniers segments comme des marges divergentes. La distribution des failles sur les segments de marges divergentes suggère qu'elles ont enregistré au moins deux phases de déformation. Une première phase d'ouverture, probablement orientée NW-SE, a affecté la marge sud-Baléares et créé de la croûte océanique. L'existence de segments transformants et l'orientation clairement NW-SE des linéations magnétiques de l'est du Bassin algérien suggèrent que ce bassin s'est ouvert principalement suivant une direction NE-SW, formant différents corridors océaniques. Nous proposons que les corridors de l'est du bassin se soient formés par une dérive vers le sud-ouest des Kabylies. Le corridor ouest, limité par les segments transformants de la marge Sud-Baléares et par la marge algérienne, résulte de la dérive vers le sud-ouest du domaine d'Alboran, comme suggéré par des études précédentes.
\end{abstract}

1. Géosciences Environnement Toulouse (GET), Observatoire Midi Pyrénées, Université de Toulouse, CNRS, IRD, 14 avenue E. Belin, F-31400 Toulouse, France. Manuscript received on June 11, 2014; accepted on October 21, 2014. 


\section{INTRODUCTION}

The western Mediterranean is a complex area composed of several basins, floored by oceanic (Liguro-Provençal, Algerian and Tyrrhenian basins) or thinned continental lithosphere (Valencia trough, West Alboran basin), surrounded and separated by thrust belts (Betic-Rif, Tell, Apennines, Alps) (fig. 1). This complex setting results from the interaction between orogenic and extensional processes, within the framework of the convergence between Africa and Eurasia. A large number of local and regional studies, and reconstruction models of the evolution of the western Mediterranean, have been presented in a vast literature. It is commonly accepted that widespread extension started in Oligocene time when the convergence between Africa and Eurasia slowed down and the northward subduction of the old oceanic Tethys lithosphere started to retreat [e.g., Tapponnier, 1977; Malinverno and Ryan, 1986; Royden, 1993; Lonergan and White, 1997]. Back-arc extension led to the fragmentation of the Mesozoic-Early Cenozoic Alpine orogenic belt into different continental blocks [Bouillin et al., 1986], whose migration allowed for the opening of the Neogene basins [e.g., Rehault et al., 1984].

The nature of the crust in the different basins has been partly constrained by geophysical studies, and the motion of continental blocks by paleomagnetic measurements. The location of subduction zones has been evidenced by the associated volcanism, the seismicity, and the seismic tomography. Based on these observations, two types of models of palinspastic reconstructions have been proposed for the western Mediterranean (fig. 2). All models agree on two points: (1) the NW-SE opening of the Liguro-Provençal basin, with the counterclockwise rotation of Corsica and Sardinia; (2) the important role of the North Balearic fracture zone [Mauffret et al., 1995], located east of Menorca and representing the boundary between the Valencia trough or the Algerian basin to the west and the Liguro Provençal basin to the east (fig. 1). The models differ on the kinematics of opening of the Algerian basin and the behavior of the retreating subduction. The first type of models (fig. 2a) suggests that the Valencia trough, the Liguro-Provençal and the Algerian basins opened in a similar, NW-SE direction, at different times [Boccaletti and Guazzone, 1974; Rehault et al., 1984; Gueguen et al., 1998; Vergès and Sabàt, 1999; Zeck and Whitehouse, 1999; Rosenbaum and Lister, 2004; Guerrera et al., 2005; Schettino and Turco, 2006; Vergès and Fernandez, 2012; Carminati et al., 2012]. The Liguro-Provençal basin and the Valencia trough formed in the late Oligocene-early Miocene as a result of the eastward roll-back of the Calabrian slab and the rotation of the Corso-Sardinian block (CSB) [Rehault et al., 1984; Gattacecca et al., 2007]. The Algerian basin opened in the middle Miocene due to the southward migration of the Maghrebian trench. This type of models does not suggest any westward motion of continental block [Rehault et al., 1984; Vergès and Sabàt, 1999; Zeck and Whitehouse, 1999; Guerrera et al., 2005; Schettino and Turco, 2006; Vergès and Fernandez, 2012] or a very limited westward motion compared to the southward one [Facenna et al., 2004; Jolivet et al., 2008]. In the second type of models (fig. 2b), the Valencia trough and the Liguro-Provençal basins open in a NW-SE direction, but the Algerian basin opens in a NE-SW or E-W direction, as a result of the westward drift of the Alboran domain driven by the westward-retreating Gibraltar slab [Andrieux et al., 1971; Frizon de Lamotte et al., 1991, 2000, 2008; Rosenbaum et al., 2002; Mauffret et al., 2004; Spakman and Wortel, 2004; Bezada et al., 2013; Medaouri et al., 2014; Van Hinsbergen et al., 2014] or dragged by a mantle flow [Mattauer, 2007]. Some of these models also include an episode of N-S extension [Frizon de Lamotte et al., 1991, 2000, 2008; Rosenbaum and Lister, 2004].

While many studies have been conducted in the Liguro-Provençal basin and the Alboran sea, the Algerian basin and Balearic promontory have been less surveyed. Interestingly, most geodynamic models do not clearly deal with the opening of the eastern Algerian basin [Biju-Duval et al., 1978; Lonergan and White, 1997; Gueguen et al., 1998; Michard et al., 2006; Jolivet et al., 2009; Carminati et al., 2012]. The regional kinematics and chronology of opening of this area are still debated. Understanding the nature of the south Balearic margin is a key question to constrain the kinematics of the Algerian basin. In particular, the different models imply either divergent or transform motion along the southern margin of the promontory. Constraining the motion along this margin thus helps choose between the two types of kinematic models. We present a study of the Balearic promontory, using a large set of seismic reflexion profiles, as well as models of gravity anomalies across the margins, to describe its morphology, crustal structure and deformation. Our analysis leads to a new interpretation of the south Balearic margin. We include the observations of the magnetic anomaly lineations in the Algerian basin in the analysis, because they constrain the kinematics of the eastern Algerian basin. The compilation of these observations allows us to suggest a new reconstruction of this part of the western Mediterranean basin, which is more consistent with all geological and geophysical data.

\section{REGIONAL GEOLOGICAL AND GEODYNAMICAL SETTINGS}

\section{The western Mediterranean sub-basins}

The Balearic promontory separates the Valencia trough from the Algerian basin, and is bounded to the east by the Liguro-Provençal basin. These basins have distinct morphologies and structures. They also have different histories, which have partly been shared with that of the Balearic promontory.

The Liguro-Provençal basin is floored by stretched continental crust and oceanic crust narrowing to the northeast (fig. 1) [Bayer et al., 1973; Le Douaran et al., 1984; Burrus, 1984; Chamot-Rooke et al., 1999]. It is limited to the southwest by the North Balearic fracture zone [e.g., Maillard et al., 1992]. It results from the rotation of Corsica with respect to Provence, and of Sardinia with respect to the gulf of Lions, during the Oligo-Miocene (23-15 Ma) [Rehault et al., 1984; Speranza et al., 2002; Gattacceca et al., 2007].

The Valencia trough (fig. 1) is formed by stretched continental crust with widespread volcanism [Pascal et al., 1992; Torné et al., 1992]. It has been interpreted to be an aborted Oligo-Miocene continental rift [Gelabert et al., 1992; Maillard et al., 1992; Mauffret et al., 1992, 2004]. A second phase of volcanism occurred from the Late Miocene 


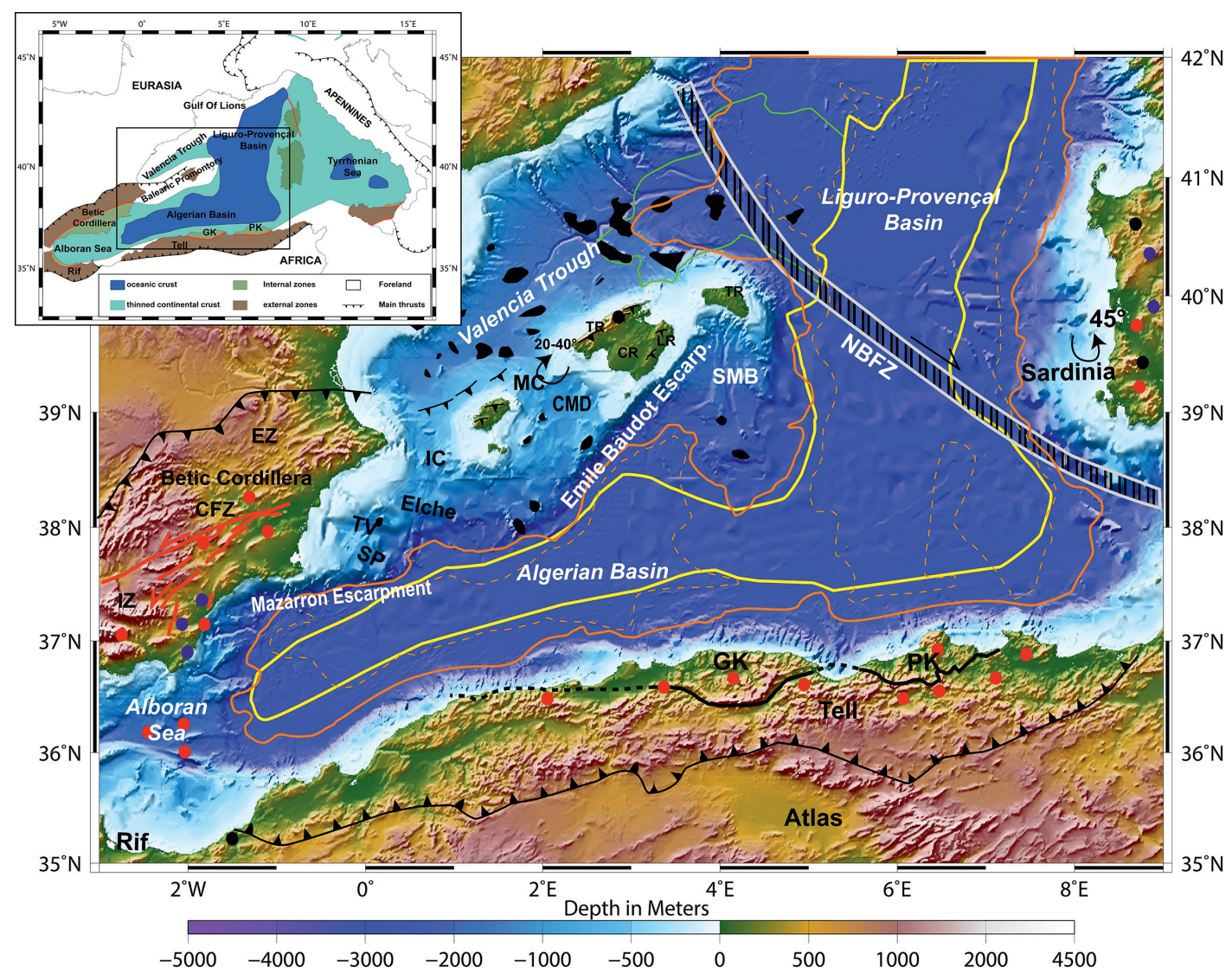

FIg. 1. - Bathymetric map of the Balearic area and major geological features of the basins and surrounding thrust belts. Black shapes are volcanic areas [from Maillard et al., 1992]. Arrows show paleomagnetic rotations [from Parès et al., 1992; Rehault et al., 1984 and Gattacceca et al., 2007]. Thick yellow line is ocean-continent boundary; thin green line is continent-transition crust boundary [both from Mauffret et al., 1995 and Mascle et al., 2012]. Blue, red and black dots are Late Miocene, Middle Miocene and Oligocene-early Miocene volcanics, respectively [from Rosenbaum et al., 2002 and Carminati et al., 2012]. Orange solid line marks the extension of the Messinian halite, and orange dashed line that of the diapirs [from Lofi et al., 2011). TR: Tramuntana ranges; LR: Llevant ranges; CR: Central ranges; TV: TorreVieja half graben; SP: San Pedro basin; SMB: South Menorca block; CFZ: Crevillente fault zone; EBE: Emile Baudot escarpement; NBFZ: North Balearic fracture zone [from Gueguen et al., 1998]; IC: Ibiza channel; CMD: Central Mallorca depression. IZ: Internal zone; EZ: External zone; GK: Grande Kabylie; PK: Petite Kabylie. (Colors refer to PDF version).

to the Quaternary, especially along the transfer zones [Rivière et al., 1981; Marti et al., 1992; Maillard and Mauffret, 1993, 1999].

The Algerian basin is narrow in the west, widening in its eastern part, and is almost entirely covered by a thick layer of Messinian evaporites, including $1500 \mathrm{~m}$ of halite (fig. 1). Refraction profiles show that the crust in the Algerian basin is 5.5 to $6 \mathrm{~km}$ thick and is oceanic in nature [e.g., Vidal et al., 1998; Catalano et al., 2000; Hübscher et al., 2010]. Moreover, they display an abrupt crustal thinning across the Mazzaron and Emile Baudot scarps, while the thinning is more progressive in the Ibiza channel [Hübscher et al., 2010]. The western and eastern parts of the basin are separated, south of Menorca island, by a basement high called the Hannibal ridge, and interpreted to be a relict oceanic spreading center by Mauffret et al. [1995, 2004].

The Alboran sea and the adjacent Betic-Rif belt result from the westward motion of the Alboran domain, still active today [Bouillin et al., 1986; Frizon de Lamotte et al., 1991; Lonergan and White, 1997; Mauffret et al., 2004; Duggen et al., 2008; Gutscher et al., 2002, 2012]. The crustal nature of the Alboran sea is similar to the internal zone of the Betics observed on land [Platt and Vissers,
1989; Comàs et al., 1996]. The central Alboran sea displays mainly Miocene tholeiitic magmas and the surrounding area (western Alboran) displays Miocene calc-alcaline magmas [Duggen et al., 2008]. These observations are consistent with the presence of an eastward-dipping slab retreating westward.

Africa is currently converging toward Eurasia at a rate of $5 \mathrm{~mm} / \mathrm{yr}$ [DeMets et al., 1990; Nocquet and Calais, 2003; Serpelloni et al., 2007]. The deformation is mainly localized in the thrust belts of North Africa. It appears to affect the Balearic promontory only west of Ibiza [Serpelloni et al., 2007]. This region shows recent strike-slip and normal faults, as well as numerous mass-wasting structures [Acosta et al., 2002, 2004a, 2004b; Lastras et al., 2004; Camerlenghi et al., 2009; Maillard and Mauffret, 2013]. The thrust belts surrounding the western Mediterranean basins (Betics, Rif, Tell) result mainly from the closure of the old Tethysian oceanic domain. The associated subducting slabs are observed in the seismic tomography images, and in the distribution of the earthquakes [e.g., Spakman and Wortel, 2004; Serpelloni et al., 2007; Van Hinsbergen et al., 2014]. 


\section{The Balearic promontory}

The Balearic promontory is a $400 \mathrm{~km}$-long, $110 \mathrm{~km}$-wide, NE-SW-trending continental high (fig. 1). It includes four major islands: Ibiza and nearby Formentera, Mallorca and Menorca, surrounded by a shallow (100 m deep) and narrow continental platform, and separated by two lows: the Ibiza channel between mainland Spain and Ibiza and the Mallorca channel between Mallorca and Menorca islands (IC and MC on fig. 1). Of the two bathymetric lows, the Ibiza channel is the deepest $(800 \mathrm{~m})$ and widest $(25$ to $45 \mathrm{~km}$ ) [Acosta et al., 2001; Acosta et al., 2013]. The Mallorca channel includes the Central Mallorca depression [Acosta et al., 2004a], which is limited to the south by the crest of the Emile Baudot escarpment (EBE). The northern Balearic margin is a NE-SW-trending steep scarp. The southern Balearic margin displays four segments: two very steep scarps, Mazarron and Emile Baudot, and two more gently-deepening segments in the Ibiza channel and the South Menorca block (SMB). The southeastward continuation of the SMB is the basement high described as the Hannibal ridge [Mauffret et al., 1995, 2004]. The eastern boundary of the Balearic promontory east of the SMB is the North Balearic fracture zone (NBFZ).

The Balearic promontory is one of the small continental blocks which detached from the Eurasian margin behind the retreating Tethysian subducting slab: the Corsica, Sardinia and Balearic islands and the $\mathrm{AlKaPeCa}$ blocks [AlboranKabylies-Peloritan-Calabria, Bouillin et al., 1986]. It is thus the result of the complex interaction of both shortening and extensional events during the Miocene. It underwent Oligo-Miocene extension related to the formation of the Valencia trough, but also thrusting related to the formation of the external Betic-Rif belt, an Oligocene to middle Miocene thrust belt extending from the Gibraltar arc to the Balearic promontory [Bourrouilh, 1973; Ramos Guerrero et al., 1989; Sanz de Galdeano et al., 1990; Fontboté et al., 1991, Roca, 2001; Sabàt et al., 2011] (fig. 1). Observations on the
Balearic islands, mainly on Ibiza and Mallorca Tramuntana, Central and Llevant ranges, show Mesozoic units thrusting Cenozoic units, along thrusts trending ESE-WNW with a top-to-the-northwest motion [Canals and Pujades, 1992; Durand-Delga and Fontboté, 1980; Fourcade et al., 1982; Gelabert et al., 1992, 2004; Sabàt et al., 2011]. Offshore, Betic thrusts have also been observed north of Ibiza or Mallorca [Maillard et al., 1992; Maillard and Mauffret, 1993; Roca and Guimera, 1992]. It is still debated whether the thrusts affect the whole margin [Roca and Guimera., 1992; Roca, 2001; Gelabert et al., 1992] or stop near Mallorca [Maillard et al., 1992; Mauffret et al., 1992]. A paleomagnetic study showed that during this event the island experienced a clockwise rotation (fig. 1) [Parès et al., 1992].

The Balearic promontory then underwent a postorogenic extensional event from the late Serravalian [Cespedes et al., 2001] to Recent, associated to a second clockwise rotation of the Promontory [Parès et al., 1992]. This event led to the formation of Miocene basins outcropping on the different islands such as the Palma graben. It also affected the northern Balearic margin [Maillard et al., 1992, 2014]. The main extension direction is WNW-ESE but locally a secondary axis is consistent with an ENEWSW direction [Sabàt et al., 2011]. Local compressional events occurred at the same time on Ibiza [Durand-Delga and Fontboté, 1980; Fourcade et al., 1982] or on Menorca [Bourrouilh, 1973].

A NE-SW refraction profile along the Balearic promontory (blue stars on figure 3) [Banda et al., 1980] shows that it consists of continental crust, with an average thickness of $22 \mathrm{~km}$ and velocities ranging from $6 \mathrm{~km} / \mathrm{s}$ in the upper crust to $6.6 \mathrm{~km} / \mathrm{s}$ in the lower crust. Banda et al. [1980] also suggest that the lower crust has a constant thickness of $10 \mathrm{~km}$. Other models confirm this crustal structure and the rapid crustal thinning to the south [Ayala et al., 2003; Schettino and Turco, 2006].



FIG. 2. - Illustrations of the two main types of models proposed for the opening of the western Mediterranean basin. A. General NW-SE opening [Zeck and Whitehouse, 1999]. B. Westward opening of the Algerian basin [Mattauer, 2007]. 


\section{DATASETS AND METHODS}

In order to study the shallow sedimentary and crustal structures of the margin, we analyzed a large seismic database (fig. 3). This database includes academic profiles from former cruises: BAL84 [Curzi et al., 1985], VALSIS2 [Mauffret et al., 1992; Torné et al., 1992; Pascal et al., 1992]. New academic lines have been added: CARBMED [Hübscher et al., 2010; Just et al., 2011], SIMBAD [Driussi et al., 2014]. Industrial profiles include old data: RAY (Mandrel Industry, 1972), ALE (Total, 1974), Map (ENIEPSA, 1977), Meds (ENIEPSA, 1977) and SH (Sonatrach, 1977). Most of these old surveys can be found on the Spanish Geological Survey database: SIGEOF (www.igme.es). Most of the seismic profiles have been transformed from a tiff format associated with a navigation text file into SEG-Y format using the IMAGE2SGY software, a free SEG-Y tool developed at the Institute of Marine Sciences of Barcelona [Farràn, 2008]. The profiles have then been integrated into a Kingdom Suite project for comparison and interpretation.

For each profile, we distinguished the main horizons characterizing the structure of the margins: the seafloor, the base and top of the unit related to the Messinian Salinity Crisis (MSC), and the top of the acoustic basement. We then distinguished four seismic units based on their seismic facies, the most prominent facies being that of the Messinian unit:

- the Plio-Pleistocene unit (PP unit), above the MSC unit,

- the MSC unit, or its time equivalent Messinian erosion surface (MES), when MSC deposits are absent. The MSC unit consists of 2 sub-units, the MSC Upper Unit (UU) and the MSC Mobile Unit [MU, for the halite layer, Lofi et al., 2011],

- the pre-MSC unit, which is mostly Miocene in age but possibly older (Oligocene),

- the acoustic basement, which is characterized by a chaotic facies, and represents either igneous rocks or Mesozoic sediment. This basement includes the pre-Cenozoic units. It sometimes displays internal horizons which must be related to the Mesozoic sediment, but most often the old sediment cannot be distinguished from igneous basement.

The seismic interpretations have been tied with the wells available in the region: DSDP sites 123, 122, 124 and 372 [Hsü et al., 1973, 1978], ODP sites 973 and 975 [Comàs et al., 1996] (green stars on figure 3) and industrial wells located on the eastern Spanish margin [Ochoa et al., 2014]. The seismic interpretations were also adjusted to ensure consistency with published seismic lines at crossing points [Maillard et al., 1992; Roca and Guimera, 1992; Sabàt et al., 1997; Gallart et al., 1994; Acosta et al., 2001b; Just et al., 2011]. All major faults and volcanic structures have been mapped. The seismic lines are presented in time sections. To convert the velocity in depths and compile the depth-to-basement map, we used a velocity of $1.5 \mathrm{~km} / \mathrm{s}$ in the seawater, and the sediment velocity are from Maillard et al. [1992] based on the study of detailed depths versus time curves and data from wells and ESP [Pascal et al., 1992].

In order to study the deep crustal structure and main crustal boundaries, we analyzed the magnetic anomalies [from Galdeano et al., 1974; Galdeano and Rossignol,
1977], and the free-air gravity anomalies derived in the oceans from satellite altimetry [Bonvalot et al., 2012] (fig. 3). We also performed 2-D modeling of the crustal structure along profiles across or along the Balearic promontory and the South Menorca block. The shallow structure in the models was constrained by our interpretations of seismic profiles, as well as by previously published seismic data. The deep structure was constrained by ESP [Pascal et al., 1992] and some other refraction seismic profiles. Adjustment of the crustal structure along the models was performed using Geosoft Oasis Montaj GM-SYS. The density


FIG. 3. - A. Free-air gravity anomalies [from Bonvalot et al., 2012], showing crustal data. Black lines: ESCI profiles [Gallart et al., 1994; Vidal et al., 1998], Meteor profiles [Hübscher et al., 2010], and Spiral profile (black stars on-shore) [Lepretre et al., 2013]. Blue and yellow stars: Banda et al. [1980]. Red lines: gravity models from this study. Yellow lines: seismic profiles. B. Magnetic anomalies [from Galdeano and Rossignol, 1977]. Contours show magnetic values higher than $20 \mathrm{nT}$. The two white boxes highlight gaps between the original aeromagnetic surveys where anomalies have been interpolated from scarcer data points. The green line represents the boundary between continental and transitional crusts and the yellow one, the boundary between transitional and oceanic crusts. C. Location map of the seismic lines used for this study. (Colors refer to PDF version). 
of each unit was calculated from the seismic velocities estimated from the refraction data (Banda, ESCI, ESP and the recent models from Ayala et al. [2003] or Schettino et Turco [2006]), using the "Nafe-Drake278 Curve" from Ludwig et al. [1970], and the subsequent models inferred from this equation [Christensen and Mooney, 1995; Brocher, 2005]. The estimated densities for the sediments are $1.8,2.0,2.2$, and $2.4 \mathrm{~g} / \mathrm{cm}^{3}$ for the Plio-Pleistocene unit, the thin MSC Upper unit, the thick MSC mobile unit and the pre-MSC unit, respectively. Densities for the upper and lower continental crust, transitional crust, oceanic crust and mantle are $2.8,2.9,2.85,2.9$ and $3.3 \mathrm{~g} / \mathrm{cm}^{3}$, respectively. The aim of the models was to optimize the fit between the observed free-air gravity anomalies and the ones calculated from the distribution of densities. The main variables were the nature and thickness of the crust. That allowed us to constrain the width and thickness of the continental, transitional, and oceanic crust along the profiles.

\section{RESULTS}

\section{Structure of the southern Balearic margin}

We describe the structure of the margin on typical seismic profiles (fig. 3). All the observations from the seismic reflexion profiles have been combined to provide the detailed structural map of the Balearic promontory (fig. 4, C1 and C2). These structural interpretations are presented on a broader map of the depth to basement (fig. 4), integrating the Valencia basin [Maillard et al., 1992, 1999], and the Algerian basin [Mauffret et al., 2004]. The deep structure and the nature of the crust have been constrained by the fit of free-air gravity anomalies on 2D models whose shallow part corresponds to seismic profiles. We used the free-air gravity and the magnetic anomaly maps (fig. 3) to better locate the continent-ocean boundaries and to identify the main structures observed in the oceanic basins. A large part of the West Mediterranean ocean basin is covered by a thick evaporite layer (fig. 1). This layer makes it difficult to identify reflectors beneath the MSC salt where the latter is thick and affected by diapirs. Therefore, the bottom of the continental slope is often hidden, in particular along the steep scarps of Mazarron and Emile Baudot. The southern margin of the Balearic promontory is characterized by large variations of morphology and structure, defining four segments from west to east: the Mazarron escarpment, the South Ibiza margin, the Emile Baudot escarpment, and the South Menorca margin.

\section{Mazarron escarpment}

The Mazarron escarpment (ME) is a $\sim 145 \mathrm{~km}$-long, linear, E-W-trending scarp, limiting the deep Algerian basin from the westernmost part of the Balearic promontory (Alicante continental platform). It is marked both by a steep scarp in the bathymetry (1500 m vertical offset on average, fig. 1), and by a rapid deepening of the acoustic basement (fig. 4). It has a maximum height of $2400 \mathrm{~m}$ above the surrounding seafloor and a declivity from $14^{\circ}$ to $31^{\circ}$ [Acosta et al., 2013]. The density of the available seismic lines is irregular in this area. The seismic profile across the ME (fig. 5, Y-Y') shows a $2.3 \mathrm{~s}$ TWTT step in the basement (fig. 5, zoom 1). No clear fault is observed, and we infer that the escarpment is the result of a series of faults rather than a single one. A thick layer of MSC evaporites prevents us from following the basement south of the ME in the deep Algerian basin (fig. 5). Rare faults are observed on the promontory north of the scarp, limiting the San Pedro basin or the Torre-Vieja graben (fig. 5). In the San Pedro basin, normal faults offset the acoustic basement and the pre-MSC sediments. The Torre-Vieja graben faults offset the basement and the MSC layers (fig. 5, zoom 2). The faults are difficult to correlate from one profile to another. They appear to have a small lateral extent (fig. 4). We also observe flexures, which affect both the acoustic basement and the sedimentary layers on the promontory (Cogedor high, zoom 2, fig. 5). These folds result from the Pleistocene compression, also marked by anticlines on the Alicante shelf [Cogedor and Tabarca highs, Maillard and Mauffret, 2011; Alfaro et al., 2012]. Small volcanoes are observed on these highs (fig. 4), consistent with those mapped by Acosta et al. [2013].

Modeling of the gravity anomalies suggests that the westernmost Balearic promontory consists of a 20-22 km-thick continental crust (fig. 6, A-A'). The thickness of the upper crust appears to decrease from 13 to $10 \mathrm{~km}$ from $\mathrm{N}$ to $\mathrm{S}$ on the promontory. The gravity anomalies are best explained by a southward change to transition crust and a rapid crustal thinning from 18 to $12 \mathrm{~km}$ across the Mazarron escarpment. The transition crust rapidly thins oceanward from 12 to nearly $6 \mathrm{~km}$ in about $15 \mathrm{~km}$. The Algerian basin is modeled with a 5 to $6 \mathrm{~km}$-thick ocean crust (fig. 6, A-A') consistent with the previous studies [Vidal et al., 1998; Hübscher et al., 2010].

The morphology of the scarp, and the abrupt thinning of the continental crust resulting in a sharp continent-ocean transition, led us to interpret this section of margin as a transform margin.

\section{Southern Ibiza margin}

South of Ibiza and Formentera islands, the Ibiza channel is characterized by a series of basins bounded by south-dipping faults, forming tilted blocks getting deeper toward the Algerian basin (fig. 4; fig. 5 Z-Z'). The overall structure of the Ibiza margin displays tilted blocks dipping to the NNW. The acoustic basement displays several steps, about $1 \mathrm{~s}$ TWTT each. The two northern basins present sedimentary fans in the pre-MSC unit, which indicate syn-sedimentary, SSE-dipping faults (fig. 5, zoom 3). The northern faults have a larger vertical throw, up to about $2 \mathrm{~s}$ TWTT. They affect the Pliocene, but do not reach the most recent sediments. The southern faults have smaller offsets but appear to be currently active. Some chaotic reflectors in the basement might be interpreted as volcanoes.

The gravity modeling across the Ibiza margin (fig. 6, B-B') suggests that the promontory consists of a 10-22 km-thick continental crust, in this area. The top $5 \mathrm{~km}$ of the upper crust could be Mesozoic cover, as observed on ESP-7 [Pascal et al., 1992], although the limit of the Mesozoic basin is unclear on the Balearic promontory. The crust reaches its maximum thickness of $22 \mathrm{~km}$ in the shallowest part of the promontory, and then progressively thins toward the south to reach $14 \mathrm{~km}$ near the Algerian basin. The thickness of the upper crust appears to be nearly constant while the lower crust tends to thin down to $2 \mathrm{~km}$ (fig. 6 B-B'). A good fit is obtained with a $7 \mathrm{~km}$-wide zone of $10 \mathrm{~km}$-thick 
transition crust between $200 \mathrm{~km}$ and $230 \mathrm{~km}$. The Algerian basin displays a 5 to $6 \mathrm{~km}$-thick ocean crust. Our results are consistent with previous studies [Hübscher et al., 2010; Mascle et al., 2012].

\section{Emile Baudot escarpment}

The Emile Baudot escarpment (EBE) is a $180 \mathrm{~km}$-long, linear, NW-SE trending segment, eroded by a complex canyon system and intruded by late Pliocene alkaline basalt [Acosta et al., 2001a, 2001b, 2004a, 2004b; Camerlenghi et al., 2009; Lüdmann et al., 2011]. Its height varies from 1400 to $1600 \mathrm{~m}$, and its declivity varies from 3 to $7^{\circ}$ in the upper part of the scarp and from $6^{\circ}$ to $12^{\circ}$ in the lower part of the scarp [Acosta et al., 2001a].

The acoustic basement shows an abrupt deepening toward the Algerian basin near the Central Mallorca depression but is less steep directly south of Mallorca island (fig. 4). West of $3^{\circ} \mathrm{E}$, the EBE shows a morphology comparable to that of the Mazarron scarp, with a large step in the acoustic basement (almost $3 \mathrm{~s}$ TWTT) but no clearly identified faults (fig. $7 \mathrm{~W}-\mathrm{W}^{\prime}$ ). The crest of the EBE consists of an acoustic basement ridge, which closes the Central Mallorca depression (fig. 4; fig. $7 \mathrm{~W}-\mathrm{W}^{\prime}$ ). The entire sedimentary sequence onlaps the ridge, suggesting that the scarp formed in Miocene time (fig. 7, zoom 2). The ridge is



FIG. 4. - Structural map of the western Mediterranean area. A. Depth-to-basement map from the Alboran sea to the Sardinian margin. The basement faults, the depth to basement and the Messinian halite boundary are interpreted from the seismic database presented in figure $3 \mathrm{C}$ (B). The thin dashed lines underline the transfer zones from Maillard et al. [1992]. The green and yellow lines are continent-transition and transition-ocean crust boundaries, respectively. Pink lines are magnetic anomaly highs (from figure 3). The dashed yellow lines representing the oceanic crust boundary are modified from Medaouri et al. [2014] near the Alboran basin and from Gueguen et al. [1998], Bache et al. [2010] for the Liguro-Provençal basin. The onland geological units are modified from Bartrina et al. [1992], Roca and Guimera [1992], Maillard and Mauffret [2013] for the Iberian margin, and from Frizon de Lamotte et al. [2008] on the African margin. GK: Grande Kabylie. PK: Petite Kabylie. HR: Hannibal ridge. HMZ: Hamilcar magnetic zone. NBFZ: North Balearic fracture zone. EBE: Emile Baudot escarpment. ME: Mazarron escarpment. OE: Oran escarpment. IC:1048 Ibiza channel. MC: Mallorca channel. CMD: Central Mallorca depression. C1 and C2. Enlargements of A showing the Ibiza channel and Mallorca/Menorca structures. (Colors refer to PDF version). 
also marked by many volcanic pinnacles (fig. 4 and Acosta et al. [2001a]). Widespread volcanic material along the scarp is also suggested by chaotic seismic reflectors and magnetic anomalies, especially near the Emile Baudot seamount (fig. 3 and fig. 7 , profile W-W'). The toe of the scarp is concealed by a thick, deformed halite layer in the Algerian basin, preventing us from observing older deformation (fig. 1 and Camerlenghi et al. [2009]). Near its crest, north dipping, small-offset normal faults can be observed in the acoustic basement. The eastern part of the EBE offsets the narrow continental platform of the promontory from the western part of the South Menorca block (fig. 7, profile V-V'). Some deep reflections are observed in the acoustic basement of the SMB (fig. 7, zoom 1), which question the nature of this area.

Gravity modeling across the EBE (fig. 6, C-C') is constrained by the observations of deep crustal units on the ESCI profile [Vidal et al., 1998] and on the SPIRAL profile [Lepretre, 2012]. As for profile B-B' (fig. 6), a thick Mesozoic cover has been described onshore, but data are too fragmentary to extrapolate it offshore in our model. The Balearic promontory is modeled with continental crust reaching its maximum thickness of $23 \mathrm{~km}$ near Mallorca's western cape. From this point to the EBE, the promontory presents a progressive thinning of the crust from 23 to $18 \mathrm{~km}$ (fig. 6, C-C'). The thinning appears to occur mostly in the lower crust. The EBE coincides with a drastic shallowing of the Moho from 18 to $12 \mathrm{~km}$ depth in less than $30 \mathrm{~km}$. The area is also characterized by a large volcanic area. South of the EBE, the model suggests a $25 \mathrm{~km}$-wide and $12 \mathrm{~km}$-thick transitional crust. The Algerian basin is again modelled with a 5 to $6 \mathrm{~km}$-thick ocean crust.

As for the Mazarron escarpment, from the morphology of the scarp and the juxtaposition of the deep oceanic domain and shallow thick continental crust, we interpret the Emile Baudot escarpment as a transform margin. Both the $\mathrm{ME}$ and EBE appear to have recorded a polyphased deformation, including mostly strike-slip motion, and some extension.

\section{South Menorca block}

The South Menorca block (SMB) has a NW-SE elongation perpendicular to the general trend of the Balearic promontory. It shows a deeper basement than the Balearic promontory (fig. 4), and a deepening both in the SE and SW


FIG. 5. - Illustrations of the Mazarron escarpment and Ibiza channel. Y-Y': line drawing of the NNW-SSE Map77-148 profile crossing Mazarron escarpment. Z-Z': line drawing of the NNW-SSE Map77-142 profile crossing the Ibiza channel. Vertical exaggeration $=4.2$. Location of the profiles and detail of the depth-to-basement map are shown in lower left corner. Zoom 1 shows the seismic expression of the Mazarron escarpment. Zoom 2 displays recent deformation in the Torre-Vieja graben. Zoom 3 illustrates pre-MSC extensional tectonics. 
directions. The acoustic basement is very irregular, and appears to have been affected by several phases of extension and by volcanism (fig. 4; fig. 8 U-U' and T-T'). Some of the basement highs characterized by chaotic seismic reflectors are interpreted to be volcanoes (fig. 4). Some of them are associated with magnetic anomalies (fig. 3).

Seismic profiles in perpendicular directions (fig. 8) display normal faults dipping either NE or SW (U-U'), NW or SE (T-T'), limiting small blocks. However, the acoustic basement shows a series of NW-trending highs (fig. 4), which form tilted blocks covered with pre-MSC units and resulting from Miocene or older extension (fig. $8 \mathrm{U}-\mathrm{U}$, zoom 1). The offset of the MSC unit might be due to the paleotopography inherited from the rifting stage. However, the MSC and Plio-Pleistocene units are clearly tilted, showing a recent (at least post MSC) reactivation of some of the faults (fig. 8, both profiles), as observed in the south Ibiza margin segment. Bending and, in some parts, erosion of the MSC unit suggest a recent uplift (fig. 5, zoom 1 and fig. 8, zoom 2).

The gravity model shows a $14 \mathrm{~km}$-thick continental crust at the southern tip of the SMB, with $6 \mathrm{~km}$ of upper crust and $8 \mathrm{~km}$ of lower crust (fig. 9, D-D'). The crust thins progressively to $8 \mathrm{~km}$ to the south of the profile, with preferential thinning in the lower crust. South of the SMB, the gravity fit suggests a 7 to $8 \mathrm{~km}$-thick transitional crust with a width comparable to that observed on sections AA' and BB' (fig. 6) to the west. The Algerian basin section of the profile shows a $100 \mathrm{~km}$-wide basin, floored by a 5 to $6 \mathrm{~km}$-thick oceanic crust. A gravity anomaly low near the center of the oceanic basin is best explained by a thickening of the oceanic crust to $7 \mathrm{~km}$, which is correlated with a structural high (fig. 4). The gravity model along a section parallel to the EBE shows a $20 \mathrm{~km}$-thick continental crust close to the Menorca shelf (fig. 9 E-E'), which progressively thins southwestward to $14 \mathrm{~km}$. Thinning appears to be more important in the upper than lower crust. In the southern $90 \mathrm{~km}$ of the profile, the fit of the gravity anomaly is obtained with a 12 to $8 \mathrm{~km}$-thick transitional crust. Another profile parallel to the EBE farther south (fig. 9, F-F') shows that both the Provençal and the Algerian basins are modeled with a 5 to $6 \mathrm{~km}$-thick oceanic crust. The model also suggests the presence of a narrower transition crust west of the SMB compared to the eastern transition with the Liguro-Provençal basin (fig. 9, F-F'). The SMB is modeled with a double layered continental crust with an average thickness of $13 \mathrm{~km}$. The crustal thinning seems to be more important toward the Liguro-Provençal basin than toward the Algerian basin, but the transitional crust zone is narrower to the west (fig. 9, F-F').

\section{Structure of the southwestern Mediterranean oceanic basins}

The combined aeromagnetic surveys [Galdeano et al., 1974; Galdeano and Rossignol, 1977] provide an almost complete, high-resolution magnetic coverage of the West Mediterranean region (fig. 3). Two areas, which were not covered by the original aeromagnetic surveys, have been interpolated from scarcer data points and should be interpreted with caution (light color areas in figure 3 ). The free-air gravity anomaly map (fig. 3) also displays a complete coverage since it has been derived from satellite altimetry over the oceans.

The magnetic and gravity anomaly maps show a great complexity of the western Mediterranean sea, in particular southwest of the Liguro-Provençal basin. The North Balearic fracture zone (NBFZ) marking the western limit of the Liguro-Provençal basin is clearly observed in the magnetic and gravity maps (fig. 3) and with a clear deepening of the
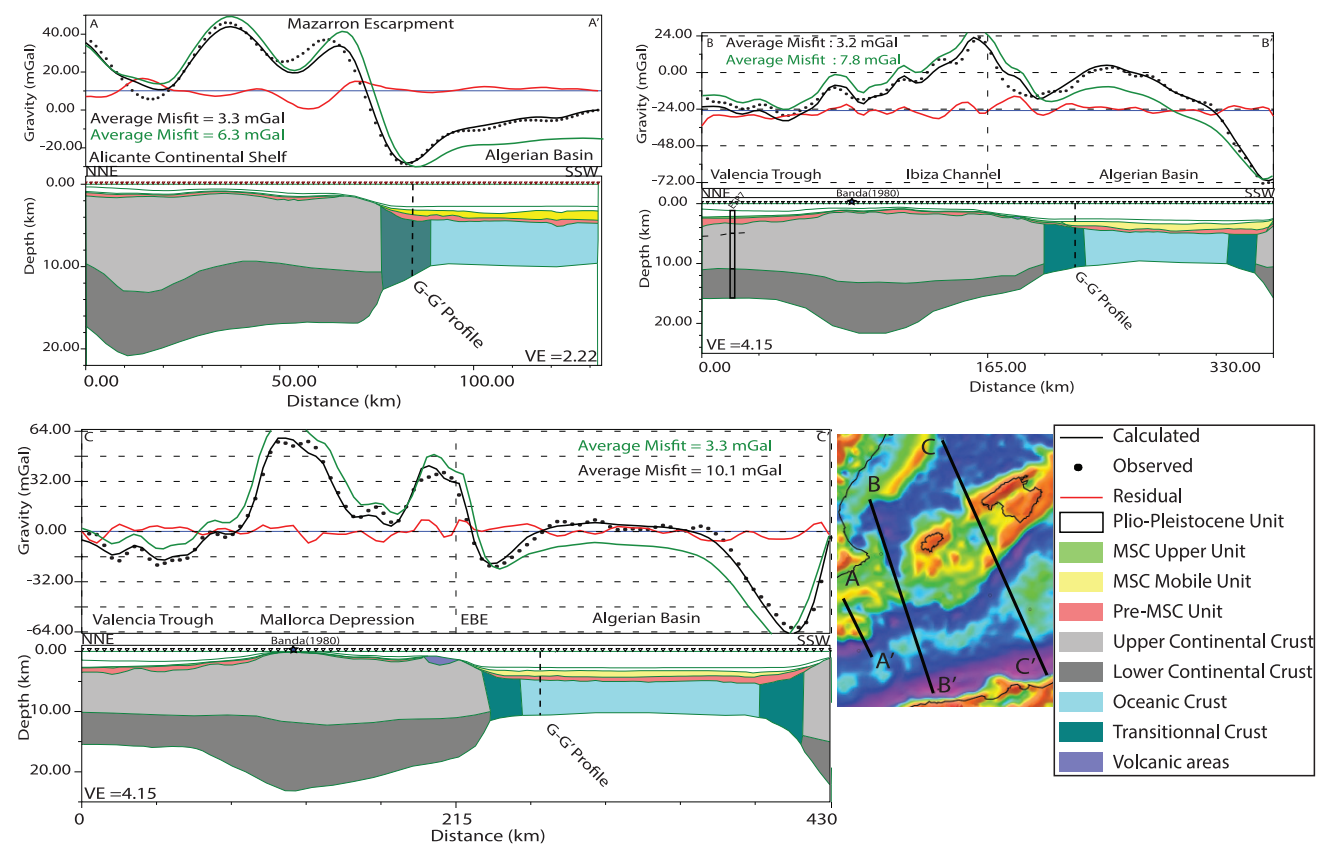

FIG. 6. - Gravity models along seismic profiles located on free-air gravity anomaly map.

A-A': model along Map77-148 profile across the Mazzaron scarp. B-B': model along Ray23, Meds77-30 and Sonatrach77-15 profiles across the Ibiza channel. C-C': model along Valsis805, Map77-132, Meds26 and Sonatrach77-20 profiles across the Mallorca Central depression and the Emile Baudot escarpment. Green line: model considering continental crust in the Algerian basin, showing a larger misfit. (Color refers to PDF version). 
basement (fig. 4). The volcanic areas in the Valencia trough and the South Menorca area are marked by high-amplitude magnetic highs and lows. This confirms the interpretation of some of the basement highs in terms of volcanoes (fig. 4, Acosta et al. [2001a, 2002]). The continent-ocean boundary $(\mathrm{COB})$ is usually well marked by a low in the free-air gravity anomaly associated with a step in the basement depth (fig. 8 to 10), allowing to define the COB between modeled gravity profiles. The north Algerian $\mathrm{COB}$ is marked by a magnetic high.

The Algerian basin area can be divided into three regions showing different types of magnetic patterns (fig. 3 ). To the east between $5^{\circ} \mathrm{E}$ and $8^{\circ} \mathrm{E}$, a domain with a general triangular shape displays the most prominent magnetic lineations of all the western Mediterranean. It is located just west of the NBZF, in the area presented as a transition zone between the Liguro-Provencal and the Algerian basins in many geodynamic models (fig. 2). The northern point of the triangle is located near $40^{\circ} \mathrm{N}, 5^{\circ} \mathrm{E}$. The gravity anomaly map shows gravity highs forming a $\mathrm{V}$-shape pointing to the same point to the NW (fig. 3), outlining the triangle, associated with highs in the magnetic anomalies, trending $\mathrm{N} 120^{\circ} \mathrm{E}$ to the east ("Hamilcar" magnetic anomaly of Mauffret et al. [2004], HMA on figure 3), and N-S to the west (fig. 3 and fig. 11). Within the $\mathrm{V}$ shape, a series of magnetic anomalies are observed, trending $\mathrm{N} 130^{\circ} \mathrm{E}$ to $\mathrm{N} 145^{\circ} \mathrm{E}$ [e.g., Bayer et al., 1973; Schettino and Turco, 2006]. The basement depth within the triangle is about $6000 \mathrm{~m}$ on average, with a deepening to $\sim 7000 \mathrm{~m}$ in the north and in the south (fig. 4). These depths are similar to those of the western part of the Algerian basin, and shallower than those of the Liguro-


FIG. 7. - Illustrations of the lateral evolution of the Emile Baudot escarpment (EBE). X-X': line drawing of the N-S Sonatrach77-19 profile crossing the western end of the EBE. W-W': line drawing of the NW-SE Map77-132 profile crossing the center of the EBE. V-V': line drawing of the NW-SE Map77-122 profile crossing the eastern end of the EBE. Vertical exaggeration $=4.2$. Location of the profiles and detail of the depth-to-basement map are shown in right corner. Zoom 1 illustrates the recent reactivation on the South Minorca block (SMB). Zoom 2 shows the closure of the southern part of the Central Mallorca depression (CMD) on the EBE. 
Provençal basin (>8000 m, fig. 4). The eastern side of the $\mathrm{V}$ coincides with the southern prolongation of the NBFZ. The northwestern edge of the $\mathrm{V}$ partly bounds the South Menorca block. Within this domain, the lineations are best defined in the center of the triangle, defining several corridors (eastern Algerian corridors, EAC, and fig. 11). The pattern of magnetic lineations implies that this region results from an oceanic opening in the NE-SW direction (fig. 11).

The second domain is observed between the SMB and the Algerian $\mathrm{COB}$ between $2^{\circ} \mathrm{E}$ and $5^{\circ} \mathrm{E}$ (fig. 3 and fig. 10). It confirms the presence of a narrow oceanic domain south of the SMB. This region is characterized by a more chaotic pattern in the magnetic anomalies, irregular gravity anomalies, and a basement depth 1000 to $2000 \mathrm{~m}$ shallower than the surroundings (fig. 3, 4 and 10), the "Hannibal ridge" [Mauffret et al., 2004]. The boundaries of the domain are not clearly observable on the gravity grid, which only shows a general NW-SE trending gravity low (fig. 3). Short magnetic lineations display directions from NE-SW just south of the SMB to NNE-SSW near the Algerian margin (fig. 3). The ocean crust in the corner formed by the EBE and the SMB is marked by magnetic and gravity anomalies with no clear trend (fig. 3 and 10). The general orientation of the magnetic lineations in this domain suggests a NNW-SSE opening. The observed shallow basement and the crustal structure obtained by gravity modeling along profile D-D' suggest a thicker oceanic crust in this domain compared to the surrounding regions.

The third magnetic region extends between $4^{\circ} \mathrm{W}$ and $2^{\circ} \mathrm{E}$ in the rest of the Algerian basin (fig. 3). In this region, the magnetic anomalies are relatively isolated, but clearly define a corridor trending NE-SW, parallel to the EBE. High-amplitude positive anomalies near $1^{\circ} \mathrm{E}$ and $0^{\circ}$ have a NW-SE trend, perpendicular to the corridor. The pattern of the observed lineations suggests that this part of the Algerian basin was created by spreading in a NE-SW direction, along short ridge segments. Such short segments separated by large transform faults have been inferred in the Alboran sea from a seismic and magnetic survey offshore Algeria [Medaouri et al., 2014]. For all magnetic anomalies observed in the western Mediterranean basin, profiles across magnetic lineations are too short to be compared to synthetic models.

\section{DISCUSSION}

\section{Segmentation and kinematics of the South Balearic margin}

The South Balearic margin displays large variations in structure and deformation (fig. 4), so that it can be divided into four different segments. The morphology and crustal structure of the ME and EBE, showing a sharp transition between continental and oceanic domains, are similar to those of well-studied transform margins, such as the Côte d'Ivoire-Ghana margin [Sage et al., 1997; Basile et al., 1993, 1998, 2013] or the Grand Bank margin [Keen et al., 1990]. Moreover, the top of the EBE could be interpreted in terms of "marginal ridge", also characteristic of transform margins, but the abundance of volcanic constructions along the scarp prevents us from describing its structure more precisely [Acosta et al., 2001a]. These two segments of the South Balearic margin can therefore be interpreted to be segments of transform margin, implying a significant strike-slip motion. A strike-slip motion along the EBE has been inferred in previous works [Lonergan and White, 1997; Acosta et al., 2001; Mauffret et al., 2004]. The relationships between the trend of the EBE and the NW-SE trending tilted blocks and normal faults on the western side

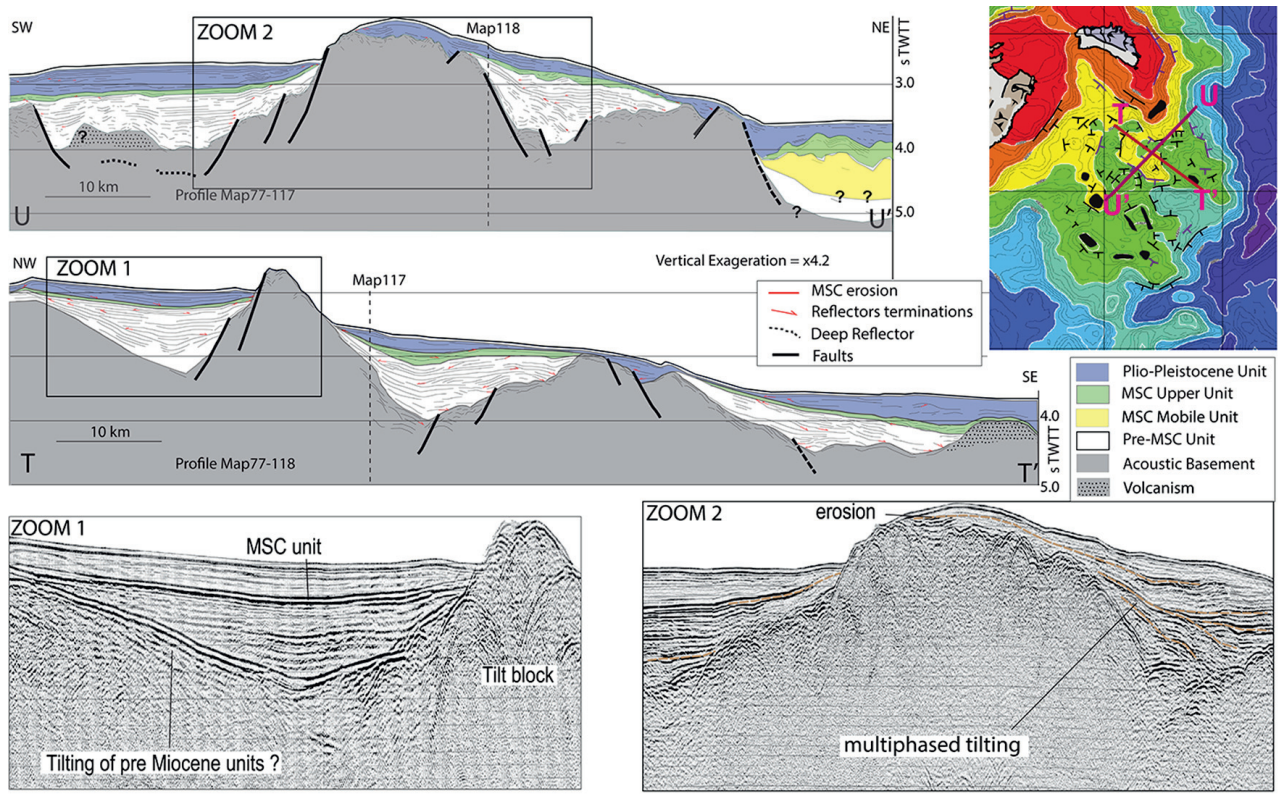

FIG. 8. - Illustrations of the South Menorca block (SMB). U-U': line drawing of the NE-SW Map77-117 profile crossing the South Menorca block. T-T': line drawing of the NW-SE Map77-118 profile crossing the South Menorca block. Vertical exaggeration = 4.2. Position of the profiles and detail of the depth-to-basement map are on the upper right corner. Zooms 1 and 2 illustrate local tilted blocks. Zoom 1 shows a clear pre-MSC activity which might be as old as Oligo-Miocene. Zoom 2 displays important Plio-Pleistocene tilting. 
of the SMB imply a dextral motion along the transform margin (fig. 4, also Acosta et al. [2001a]). A similar NW-SE trend is observed at the eastern tip of the Mazarron escarpment, but the relation between the south Ibiza margin and the Mazarron escarpment points to a more complex and probably multiphase history (fig. 4).

The other margin segments, the south Ibiza margin and the South Menorca block, are marked by a smoother bathymetry, a gentler deepening of the acoustic basement, and a more gradual thinning of the continental crust. The transition between the continental and oceanic domains is progressive. These features suggest that these segments are mostly divergent margin segments. Three types of processes, however, make the structure and kinematics along these segments more difficult to assess. First, they are affected by Miocene to recent volcanism (fig. 1 and fig. 4 , see also Acosta et al. [2002]). Second, they show evidence for recent deformation. Some of the basement faults affect the whole sedimentary cover, which shows that the region has been reactivated recently (fig. 4, also Acosta et al. [2001a, 2001b, 2013]; Alfaro et al. [2012]; Maillard and Mauffret [2013]). Finally, these margin segments appear to have been affected by different tectonic events. The south Ibiza margin displays tilted blocks, mostly oriented E-W, and S to SE dipping faults, with no evidence for strike-slip motion (fig. 4). The South Menorca block is marked by different styles of deformation on either side of the bathymetry high. On its western side, the normal faults preferentially trend NW-SE, and dip SW, whereas on the eastern side, the preferential orientation is NE-SW, with a SE dip (fig. 4). The variety of fault directions clearly suggests that the SMB has undergone different tectonic phases. The South Balearic margin from the ME to the EBE has therefore seen a transform motion in a large part of its history, but some segments of the margin have also clearly been shaped by extensional deformation. The segmentation of the margin may also reflect variations in the inherited structure of the margin, or differences in rheological properties of the continental margin. Further studies are required to understand the contrast in structure along the South Balearic margin. In the following, we focus on the implications of the transform margin motion on the kinematics of the Algerian basin.

\section{Geodynamic implications for the western Algerian basin}

Our results provide insights into the kinematics of the south Balearic margin and the Algerian oceanic basin, from which we can discuss the different geodynamic models for the opening of the Algerian basin. In the models with a N-S opening of the Algerian basin, the South Balearic margin would act as a divergent margin, while the NBFZ will act as a transform margin in the north next to the Valencia trough, and as an oceanic transform fault to the south. These models are in agreement with a southward migration of the Kabylies, but do not explain a westward drift of the Alboran block or a transform motion along segments of the south Balearic margin. In the models with an E-W or NE-SW opening of the Algerian basin, the entire southern Balearic margin would be a transform margin. This type of model would account for a westward drift of the Alboran domain but is not compatible with a southward motion of the Kabylies. Moreover, the different accretion directions between the Algerian and Liguro-Provençal basins imply a complex transition zone in the southern part of the NBFZ [Rehault et al., 1984].

The observations on the crustal structure and deformation of the South Balearic margin imply that the margin acted as a significant right-lateral transform margin. This kinematic constraint favors models where the Algerian
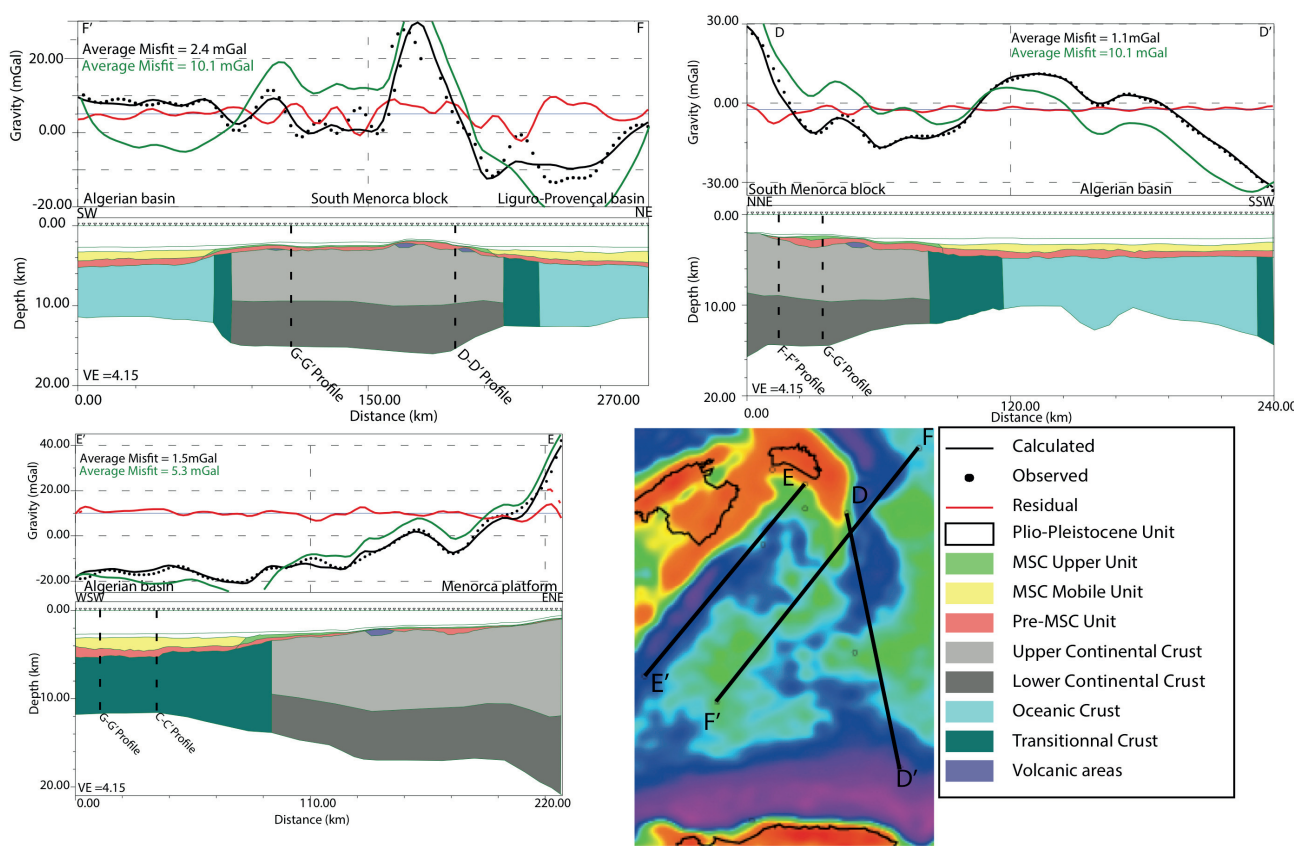

FIG. 9. - Gravity models along seismic profiles located on free-air gravity anomaly map. D-D': model along Sonatrach77-23 profile across the South Menorca block. E-E': model along Map77-109 profile across the South Menorca block. F-F': ENE model along Sonatrach77-22 and 23 profiles across the South Menorca block. Green line: model considering continental crust in the Algerian basin, showing a larger misfit. (Color refers to PDF version). 
basin opened in a general NE-SW direction. South of the margin, the magnetic and gravity anomaly maps show clear lineations in the Algerian basin, which define corridors trending E-W to NE-SW (fig. 11). Unlike what is observed in most ocean basins, however, a relict spreading center is not identifiable in the western Mediterranean. This alone suggests that, even though they were short lived, the mid ocean ridges which created seafloor in this area are likely to have had intermediate to fast spreading rates. Despite the lack of clear relict axis, the corridor of ocean lithosphere is relatively well defined by short but linear magnetic anomalies perpendicular to the EBE (fig. 11). The corner of the $\mathrm{EBE}$ and the SMB forms the northeastern boundary of the corridor. Its southern boundary is outlined by an elongated positive magnetic anomaly. To the southwest, the corridor is limited by a linear segment of the COB along the northwest Algerian margin, the Oran escarpment (OE, fig. 4). This part of the COB shows evidence for current deformation [Domzig et al., 2006]. The current compressive deformation along the northwestern margin of Algeria likely disrupts the former transform margin (fig. 11) [Deverchère et al., 2005; Domzig et al., 2006].

The northwestern boundary of the oceanic corridor described above is complex. It likely largely follows the transform scarps of the South Balearic margin, but also follows the south Ibiza margin in between (fig. 11). It is possible that the motion along the Mazarron escarpment has been partly transtensive. To the NE, the corridor extends along EBE up to the SMB. The NW-SE trending tilted blocks limiting the SMB form a divergent segment at the tip of the EBE transform segment. The corridor is closed to the east by a group of chaotic magnetic anomalies which does not seem to have any equivalent to the west.
Spreading in the corridor defined south of the EBE implies a $400 \mathrm{~km}$ westward drift of a domain about $80 \mathrm{~km}$ wide creating the western Algerian basin. Figure 11a shows the reconstruction of the area near $19 \mathrm{Ma}$, after closing the western Algerian basin using the western Algerian corridor (WAC, fig. 11b). Such kinematics are consistent with models describing the westward motion of the Alboran area along two subduction-transform edge propagator (STEP) faults [Govers and Wortel, 2005], driven by the rollback of the Gibraltar slab subduction zone [Royden, 1993; Lonergan and White, 1997; Mauffret et al., 2004; Gutscher et al., 2002, 2012; Bezada et al., 2013; Medaouri et al., 2014; Van Hinsbergen et al., 2014]. Our interpretation provides a minimum value for the motion of the Alboran domain related to its drift and seafloor spreading, which should be added to the displacement related to the continental rifting. The total amount of $500-600 \mathrm{~km}$ is compatible with previous estimates, and with the $800 \mathrm{~km}$ length of the Gibraltar subducted slab observed in tomographic images [see Van Hinsbergen et al., 2014 and references herein].

\section{Geodynamics of the eastern Algerian basin and the Kabylies}

Our observations also point to a NE-SW oceanic opening of the eastern Algerian basin, implied by the clear NW-SE orientation of the magnetic lineations (fig. 11). Such an opening for the eastern Algerian basin is actually difficult to reconstruct in detail if one assumes that the Kabylies were part of the African plate before the opening of the Algerian basin. Many observations are better accounted for by the opening of the eastern Algerian basin coeval with a southwestward drift of the Kabylies. We therefore suggest a scenario where this oceanic spreading episode was accompanied by a southwestward motion of the Kabylies, in two



FIG. 10. - Gravity models along seismic profiles located on free-air gravity anomaly map. G-G': model along Sonatrach77-36 profile across the Algerian basin. Green line: model considering continental crust in the Algerian basin, showing a larger misfit. (Color refers to PDF version). 
corridors (eastern Algerian corridor, EAC, fig. 11b) subparallel to the western Algerian corridor, driven by the rollback of the Tethysian subduction (fig. 11).

Other observations support this scenario. In particular, tomographic sections across North Africa and the Algerian basin presented in Spakman and Wortel [2004] and van Hinsbergen et al. [2014] clearly show faster velocity anomalies suggesting the presence of a slab dipping to the east under the Petite Kabylie (fig. 11b). Unlike all previous models, we suggest that the rollback of the Maghrebian slab north of Africa did not occur only toward the south, but partly to the west, like the Gibraltar slab, implying the formation of several STEP [Govers and Wortel, 2005] configurations along the north Algerian margin (fig. 11). This subduction pattern implies that the main Tethysian slab was torn into several pieces, one going to the east and forming the Tyrrhenian sea, and one going to the west and forming the entire Algerian basin, this part itself torn into the
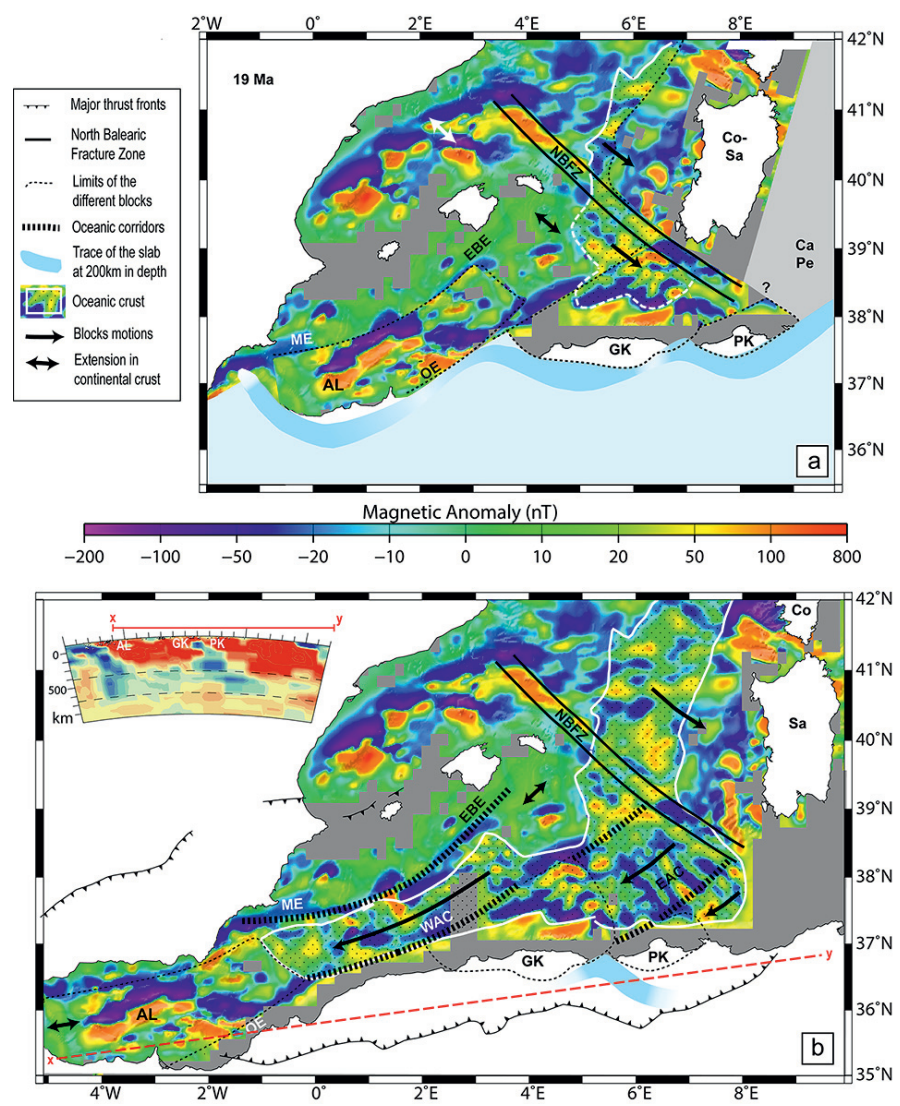

FIG. 11. - Kinematic reconstructions depicting the main features of the proposed geodynamic model, shown on the magnetic anomaly map. White lines are limits of the oceanic crust (from figure 3). NBFZ: North Balearic fracture zone, GK: Grande Kabylie. PK: Petite Kabylie, ME: Mazarron escarpment, EBE: Emile Baudot escarpment, OE: Oran escarpment, AL: Alboran domain, Co: Corsica, Sa: Sardinia, Ca: Calabria Pe: Peloritani. EAC: eastern Algerian corridors, WAC: western Algerian corridor. A. Reconstruction of western Mediterranean area before the main opening of the Algerian basin, at around $19 \mathrm{Ma}$, during the opening of the Liguro-Provençal basin. Oceanic opening occurs in a SSE-NNW direction parallel to the NBFZ. A small oceanic domain was probably forming just south of the NBFZ during a first southward motion of the GK. B. Present-day situation, after opening of the Algerian basin in a ENE-WSW direction in two main corridors. Upper left corner shows seismic tomography section across northern Africa marked by thin black line [from Spakman and Wortel, 2004].
Gibraltar slab and one or two Kabylies slabs (east Algerian slab in Wortel and Spakman [2004]. The tomographic images support this pattern. This geometry of the slab and the identification of Grande Kabylie and Petite Kabylie domains are also supported by the distribution of the seismicity. Maps of earthquake epicenters show more numerous epicenters around and between the Kabylies than elsewhere in eastern Algeria [Boughacha et al., 2004; YellesChaouche et al., 2006; Serpelloni et al., 2007]. Some earthquake hypocenters are relatively deep, possibly related to slab deformation. Further investigations about the depth and kinematics of earthquakes around the Kabylies would allow testing our scenario.

The last stage of deformation in the Kabylies is dated around $16 \mathrm{Ma}$, which constrains the opening of the eastern Algerian basin between about 19 and $16 \mathrm{Ma}$. That would be partly coeval to the end of the Liguro-Provençal spreading, and possibly to the western Algerian basin. Such a scenario implies a similar direction for the motion of the Alboran domain and the Kabylies. The amount of drift is larger for the Alboran domain than for the Kabylies (about $400 \mathrm{~km}$ vs $200 \mathrm{~km}$ of oceanic accretion, respectively). The pattern of magnetic anomalies in the west and east Algerian basins is different (fig. 3 and fig. 11), suggesting different ages or spreading rates for the two oceanic floor areas. Because of the lack of identification of magnetic anomalies, the timing of the oceanic spreading in the Algerian basin is unknown, and could only be determined by drilling of oceanic floor beneath the salt and sediment. We infer that NE-SW ocean spreading in the Algerian basin started some time near or after $19 \mathrm{Ma}$, and we have tentatively drawn a reconstruction of the basin near that time (fig. 11a). This reconstruction shows that some ocean crust formed in the Algerian basin during the opening of the Liguro-Provençal basin (fig. 11a), with the NBFZ as a transform boundary between the two domains, before the opening of the two corridors of the Algerian basin. These areas likely resulted from an episode of NW-SE extension and spreading associated with the opening of the Liguro-Provençal basin. This episode is clearly suggested by the E-W to NE-SW normal faults and structure over the Ibiza margin and the SMB. This episode of extension is probably linked to the Valencia trough rifting along NW-SE transfer faults parallel to the NBFZ, which segment the Balearic promontory (fig. 4) [Maillard et al., 1992]. These NW-SE transfer faults are still observable within NW-SE basement steps along Mallorca and Menorca but they are overprinted by the EBE (fig. 4), which tends to confirm the suggested chronology of the different phases. The succession of both extensional phases in different directions results in the complex pattern of the deformation of the SMB (fig. 4). However, the south Ibiza margin records only the NW-SE one and is not overprinted by the strike-slip motion, which could show that the EBE and the ME have been active successively.

\section{CONCLUSION}

We studied the structure of the southern Balearic margin to understand the kinematics of the adjacent basins. To this end, we interpreted a large database of seismic profiles and tested hypothesized interpretations for the margin by 
creating gravity models across the Balearic margin and the southern basins.

We show that four different segments may be distinguished along the south Balearic margin based on the morphology and structure of the margin. Two segments, the Mazarron and Emile Baudot escarpments, show steep scarps, a rapid deepening of the basement and thinning of the continental crust. The two other segments are marked by a smoother bathymetry, and a gentler deepening of the basement and thinning of the continental crust. We interpret the two steep segments as transform margin segments, implying a strike-slip motion. The two other segments are interpreted in terms of divergent margins affected by different episodes of extension and transform motion, and by recent tectonics and volcanism.

The transform motion inferred along the south Balearic margin supports models in which the Alboran domain migrates to the west or southwest with respect to Eurasia. The kinematics of the Alboran domain and the magnetic lineations in the eastern Algerian basin lead us to suggest a new scenario for the opening of the east Algerian basin. In our scenario, the Algerian basin opened shortly in a NW-SE direction, creating some seafloor just south of the North Balearic fracture zone, before a general opening in the NE-SW direction. This NE-SW oceanic spreading episode was accompanied by a southwestward motion of the Kabylies, in two corridors sub-parallel to the Alboran corridor, driven by the rollback of the Tethysian subduction to the west. The suggested motion of the Kabylies is supported by the image of a slab in the seismic tomography images, and by the distribution of earthquakes in northeastern Algeria. The different episodes of extension are recorded in some segments of the South Balearic margin.

Acknowledgements. - We thank the Guest Editor M. Séranne, D. Frizon de Lamotte, and an anonymous referee for very constructive criticisms on an earlier version of the manuscript. We are grateful to C. Hester for her help in the drafting of some figures, and to L. and E. Feigl for their help with the English style. Some of the maps have been drawn using the Generic Mapping Tools (GMT) software [Wessel and Smith, 1991].

\section{References}

Acosta J., Munoz A., Herranz P., Palomo C., Ballesteros M., Vaquero M. \& UChupI E. (2001a). - Geodynamics of the Emile Baudot escarpment and the Balearic promontory, western Mediterranean. Mar. Petrol. Geol., 18, 349-369.

Acosta J., Munoz A., Herranz P., Palomo C., Ballesteros M., Vaquero M. \& UChupi E. (2001b). - Pockmarks in the Eivissa channel the western end of the Balearic promontory (western Mediterranean) revealed by multibeam mapping. - Geo-Mar. Lett., 21, 123-130.

Acosta J., Canals M., Lopez-Martinez J., Munoz A., Herranz P., Urgeles R., PAlOMo C. \& CASAMOR J.L. (2002). - The Balearic promontory geomorphology (western Mediterranean): morphostructure and active processes. - Geomorphology, 49, 177-204.

Acosta J., Canals M., Carbó A., Munoz A., Urgeles J., Muñoz-Martín A. \& Uchupi E. (2004a). - Sea floor morphology and Plio-Quaternary sedimentary cover of the Mallorca channel, Balearic islands, western Mediterranean. - Mar. Geol., 206, 165-179.

Acosta J., Ancochea E., Canals M., Huertas M.J. \& Uchupi E. (2004b). Early Pleistocene volcanism in the Emile Baudot seamount, Balearic promontory (western Mediterranean sea). - Mar. Geol., 207, 247-257.

Acosta J., Fontán A., Muñoz A., Muñoz-Martín A., Rivera J. \& Uchupi E. (2013). - The morpho-tectonic setting of the southeast margin of Iberia and the adjacent oceanic Algero-Balearic basin. - Mar. Petrol. Geol., 45, 17-41.

Alfaro P., Delgado J., Garcia-Tortosa F.J., Lenti L., Lopez J.A., Lopez-CASSADo C. \& MARTino S. (2012). - Widespread landslides induced by the Mw 5.1 earthquake of 11 May 2011 in Lorca, SE Spain. - Engineer. Geol., 137-138, 40-52.

Andrieux J., Fontboté J.M. \& Mattauer M. (1971). - Sur un modèle explicatif de l'arc de Gibraltar. - Earth Planet. Sci. Lett., 12, 191-198.

Ayala C., Torné M. \& Pous J. (2003). - The lithosphere-asthenosphere boundary in the western Mediterranean from 3D joint gravity and geoid modeling: tectonic implications. - Earth Planet. Sci. Lett., 209, 275-290.

Bache F., Olivet J.L., Gorini C., Aslanian D., Labails C. \& Rabineau M. (2010). - Evolution of rifted continental margins: the case of the Gulf of Lions (Western mediterranean basin). - Earth Planet. Sci. Lett., 286, 139-157.
Banda E., Ansorge J., Boloix M. \& Cordoba D. (1980). - Structure of the crust and upper mantle beneath the Balearic islands (western Mediterranean). - Earth Planet. Sci. Lett., 49, 219-230.

Bartrina M.T., Cabrera L., Jurado M.J., Guimerà J. \& Roca E. (1992). - Evolution of the Central Catalan margin of the Valencia trough (western Mediterranean). - Tectonophysics, 203, 219-242.

Basile C., Mascle J., Popoff M., Bouillin J.-P. \& Mascle G. (1993). The Ivory Coast-Ghana transform margin: A marginal ridge structure deduced from seismic data. - Tectonophysics, 222, 1-19.

Basile C., Mascle J., Benkhelil J. \& Bouillin J.-P. (1998). In: J. Mascle, G.P. Lohmann, M. Moulande, Eds, Geodynamic evolution of the Côte d'Ivoire-Ghana transform margin: an overview of Leg 159 results. - Proc. ODP, Sci. Results, 159, 101-110.

Basile C., Maillard A., Patriat M., Gaullier V., Loncke L., Roest W., Mercier de Lepinay M. \& PATtier F. (2013). - Structure and evolution of the Demerara plateau, offshore French Guiana: Rifting, tectonic inversion and post-rift tilting at trasnform-divergent margins intersection. - Tectonophysics, 591, 16-29.

Bayer R., Le Mouel J.-L. \& Le Pichon X. (1973). - Magnetic anomaly pattern in the western Mediterranean. - Earth Planet. Sci. Lett., 19, 168.

Bezada M.J., Humphreys E.D., Toomey D.R., Harnafi M., Dávila J.M. \& GALlaRT J. (2013). - Evidence for slab rollback in westernmost Mediterranean from improved upper mantle imaging. Earth Planet. Sci. Lett., 368, 51-60.

Biju-Duval B., Letouzey J. \& Montadert L. (1978). - Structure and evolution of the Mediterranean basins. - Init. Rep. DSDP, 42, 951-984.

Boccaletti M. \& Guazzone G. (1974). - Plate tectonics in the Mediterranean region. Geology of Italy. - Edit. Sqyres, Petrol. Expl. Soc. Lybia., 23 p.

Bonvalot S., Balmino G., Briais A., Kuhn M., Peyrefitte A., Vales N. et al. (2012). - World gravity map. - Bureau Gravimetrique International (BGI), Map, CGMW-BGI-CNES728, IRD, Paris.

Boughacha M.S., Ouyed M., Ayadi A. \& Benhallou H. (2004). - Sesimicity and seismic hazard mapping of northern Algeria: Map of maximum calculated Intensities (MCI). - J. Seism., 8, 1-10.

Boulllin J.-P., Durand-Delga M. \& Olivier P. (1986). - Betic Rifian and Tyrrhenian arc: Distinctive features, genesis and development stages. In: F. WEZEL, Ed., The origin of arcs. - Elsevier, New York, 281-304, 
Bourrouilh R. (1973). - Stratigraphie, sédimentologie et tectonique de l'île de Minorque et du Nord-Est de Majorque (Baléares). La terminaison nord-orientale des Cordillères bétiques en Méditerranée occidentale. - Thèse, Université de Paris, 822pp.

BROCHER T.M. (2005). - Compressional and shear wave velocity versus depth in the San Francisco bay area, California: Rules for USGS Bay Area Velocity Model 05.0.0. - USGS Open-File Report, 05-1317

Burrus J. (1984). - Contribution to a geodynamical synthesis in the provençal basin through seismics and magnetics. - Mar. Geol., 55 , 247-269.

Canals J.A. \& Pujades L.G. (1992). - The Valencia trough: Coda-Q. Tectonophysics, 203, 125-132.

Camerlenghi A., Accettella D., Costa S., Lastras G., Acosta J., Canals M. \& Wardell N. (2009). Morphogenesis of the SW Balearic continental slope and adjacent abyssal plain, western Mediterranean sea. - Int. J. Earth Sci. (Geol. Rundsch), 98, 735-750.

Carminati E., Lustrino M. \& Doglioni C. (2012). - Geodynamic evolution of the central and western Mediterranean: Tectonics versus igneous petrology constraints. - Tectonophysics, 579, 173-192.

Catalano R., Franchino A., Merlini S. \& Sulli A. (2000). - A crustal section from the eastern Algerian basin to the Ionian ocean (Central Mediterranean). - Mem. Soc. Geol. It., 55, 71-85.

Cespedes A., Giménez J. \& Sàbat F. (2001). - Caracterización del campo de esfuerzos neógenos en Majorca mediante el análisis de poblaciones de fallas. - Geogaceta, 30, 199-202.

Chamot-Rooke N., Gaulier J.-M. \& Jestin F. (1999). - Constraints on Moho depth and crustal thickness in the Liguro-Provencal basin from a 3D gravity inversion. In: B. Durand, L. Jolivet, F. Horvath \& M. Séranne, Eds, The Mediterranean basin: Tertiary extension within the Alpine orogene. - London Geol. Soc., Sp. Publ., 156, 37-61.

Christensen N.I. \& Mooney W.D. (1995). - Seismic velocity structure and composition of the continental crust: A global view. - J. Geophys. Res., 100, 9761-9788.

ComÀs M.C., Zahn R., Klaus A. et al. (1996). - Site 976. - Proc ODP, Init. Reports, College Station, TX (Ocean Drilling Program), 161, 179-297.

Curzi P.V., Fornos J., Mauffret A., Sartori R., Serra J., Zitellini N., Borsetti A.M., Canals M., Castellarin A., Pomar L., Rossi P.L. \& SABÀT F. (1985). - The South Balearic margin (Menorca rise): objectives and preliminary results of the cruise $768 \mathrm{Bal}-84$. Rend. Soc. Geol. It., 8, 91-96.

DeMets C., Gordon R. G., Argus D.F. \& Stein S. (1990). - Current plate motions. - Geophys. J. Int., 101, 425-478.

Deverchère J., Yelles K., Domzig A., Mercier de Lépinay B., Bouillin J.-P., Gaullier V., Bracène R., Calais E., Savoye B., KherRoubi A., Le Roy P., Pauc H. \& DAn G. (2005). - Active thrust faulting offshore Boumerdes, Algeria, and its relations to the 2003 Mw 6.9 earthquake. - Geophys. Res. Lett., 32, L04311, doi: $10.1029 / 2004$ GL021646.

Driussi O., Maillard A., Ochoa D., Lofi J., Chanier F., Gaullier V., Briais A., Sage F., Sierro F. \& Garcia M. (2014). - Messinian salinity deposits widespread over the Balearic promontory: insights from new high-resolution seismic data. - Mar. Petrol. Geol., doi: 10.1016/j.margeo.2014.10.001

Domzig A., Yelles K., Le Roy C., Déverchère J., Boulllin J.-P., Bracène R., Mercier de Lépinay B., Le Roy P., Calais E., Kherroubi A., Gaullier V., Savoye B. \& Pauc H. (2006). - Searching for the Africa-Eurasia Miocene boundary offshore western Algeria (MARADJA'03 cruise). - C. R. Geoscience, 338, 80-91.

Duggen S., Hoernle K., Klu“gel A., Geldmacher J., Thirlwall M., HAufF F., Lowry D. \& OATES N. (2008). - Geochemical zonation of the Miocene Alboran basin volcanism (westernmost $\mathrm{Me}-$ diterranean): geodynamic implications. - Contrib. Mineral. Petrol., 156, 577-593.

Durand-Delga M. \& Fontboté J.M. (1980). - Le cadre structural de la Méditerranée occidentale. - Intern. Geol. Congr. 26th, C5, 67-85

Faccenna C., Piromallo C., Crespo-Blanc A., Jolivet L. \& Rossetti F. (2004). - Lateral slab deformation and the origin of the western Mediterranean arcs. - Tectonics, 23, TC1012.

FARRAN M. (2008). - IMAGE2SEGY: A software to convert seismic profiles 792 images to SEG-Y files. - Geo-Temas, 10, 1215-1218.
Fontboté J.M., Guimerà J., Roca E., Sàbat F., Santanach P. \& FernanDEZ-Oritgosa F. (1991). - The Cenozoic geodynamic evolution of the Valencia trough (western Mediterranea). - Rev. Soc. Geol. Espana, 3, 249-259.

Fourcade E., Chauve P. \& Chabrier G. (1982). - Stratigraphie et tectonique de l'île d'Ibiza, témoin du prolongement de la nappe subbétique aux Baléares (Espagne). - Eclogae geol. Helv., 75 (2), 415-436.

Frizon de Lamotte D., Andrieux J. \& Guézou J.C. (1991). - Cinématique des chevauchements néogènes dans l'arc bético-rifain, discussions sur les modèles géodynamiques. - Bull. Soc. géol. Fr., 162, 611-626.

Frizon de Lamotte D., Saint Bezar B. \& Bracène R. (2000). - The two main seps of the Atlas building and geodynamics of the western Mediterranean. - Tectonics, 19 (4), 740-761.

Frizon de Lamotte D., Zizi M., Missenard Y., Hafid M., El Azzouzi M., Maury R.C., Charriere A., Taki Z., Benammi M. \& Michard A. (2008). - The Atlas system. - Lect. Notes Earth Sci., 116, 133-202.

Frizon de Lamotte D., Raulin C., Mouchot N., Wrobel-Daveau J.-C., Blanpied C. \& Ringenbach J.-C. (2011). - The Southernmost margin of the Tethys realm during the Mesozoic and Cenozoic: Initial geometry and timing of the inversion processes. - Tectonics, 30, TC3002, doi: 10.1029/2010TC002691.

Galdeano A. \& Rossignol J.-C. (1977). - Assemblage à altitude constante de cartes d'anomalies magnétiques couvrant l'ensemble du bassin occidental de la Méditerranée. - Bull. Soc. geol. Fr., 7, (XIX, 3), 461-468

Galdeano A., Courtillot V., Le Borgne E., Le Mouel J.-L. \& RossiGNOL J.-C. (1974). - An Aeromagnetic survey of the southwest of the western mediterranean: description and tectonic implications. - Earth Planet. Sci. Lett., 23, 323-336.

Gallart J., Vidal N. \& Dañobeitia J.J. (1994). - ESCI-Valencia Trough Working 815 Group, Lateral variations in deep crustal structure at the Iberian margin of the Valencia trough imaged from seismic reflection methods. - Tectonophysics, 232, 59-75.

Gattacceca J., Deino A., Rizzo R., Jones D.S., Henry B., Beaudoin B. \& VAdEBoin F. (2007). - Miocene rotation of Sardinia: New paleomagnetic and geochronological constraints and geodynamic implications. - Earth Planet. Sci. Lett., 258, 359-377.

Gelabert B., SÀbat F. \& Rodríguez-Perea A. (1992). - A structural outline of the Sierra the Tramontana of Majorca (Balearic islands). - Tectonophysics, 203, 167-183.

Gelabert B., Sàbat F., Hardy S. \& Rodríguez-Perea A. (2004). - Significance of inherited normal faults during inversion tectonics: an example from the Tramuntana range, Mallorca. - Geodin. Acta, 17, 363-373.

Govers R. \& Wortel M.J.R. (2005). - Lithosphere tearing at STEP faults: Response to edges of subduction zones. - Earth Planet. Sci. Lett., 236, 505-523.

Gueguen E., Doglioni C. \& Fernández M. (1998). - On the post-25 Ma geodynamic evolution of the western Mediterranean. - Tectonophysics, 298, 259-269.

Guerrera F., Martin-Martin M., Perrone V. \& Tramontana M. (2005). - Tectono-sedimentary evolution of the southern branch of the western Tethys (Maghrebian flysch basin and Lucanian ocean): consequences for western Mediterranean geodynamics. - Terra Nova, 17, 358-367.

Gutscher M.-A., Malod J., Rehault J.-P., Contrucci I., Klingelhoefer F., Mendes-Victor L. \& Spakman W. (2002). - Evidence for active subduction beneath Gibraltar. - Geology, 30, 1071-1074.

Gutscher M-A., Dominguez S., Westbrook G.K., Le Roy P., Rosas F., Duarte J.C., Terrinha P., Miranda J.M., Graindorge D., Gailler A., Sallares V. \& Bertolome R. (2012). - The Gibraltar subduction: A decade of new geophysical data. - Tectonophysics, 574-575, 72-91.

Hsü K.J., CitA M.B. \& RyAn W.B.F. (1973). - The origin of the Mediterranean evaporites. - Init. repts Deep Sea Drill. Proj., 13 (1-2). U-S Govt. Printing Office, Washington, DC, 1203-1231

Hsü K.J., Montadert L. et al. (1978). - Initial reports of the Deep Sea Drilling Project, U.S. Govt. Printing Office, Washington, DC. 42, 1079-1094. 
Hübscher C., Betzler C. \& Grevemeyer I., Eds (2010). - Sedimentology, rift-processes and neotectonic in the western Mediterranean, Cruise no. 69, August 08 - September 20, 2006. - Universität Hamburg, METEOR-Berichte, 10-1, 86 pp,

Jolivet L. Augier R., Faccenna C., Negro F., Rimmele G., Agard P., Robin C., Rossetti F. \& Crespo-Blanc A. (2008). - Subduction, convergence and the mode of backarc extension in the $\mathrm{Me}$ diterranean region. - Bull. Soc. géol. Fr., 179 (6), 525-550.

Jolivet L., Faccenna C. \& Piromallo C. (2009). - From mantle to crust: stretching the Mediterranean. - Earth Planet. Sci. Lett. 285, 198-209.

Just J., Hübscher C., Betzler C., Lüdmann T. \& Reicherter K. (2011). Erosion of continental margins in the western Mediterranean due to sea-level stagnancy during the Messinian salinity crisis. Geo-Mar. Lett., 31, 51-64

KeEn C.E., KAY W.A. \& Roest W.R. (1990). - Crustal anatomy of a transform continental margin. - Tectonophysics, 173 (1-4), 527, doi: 10.1016/0040-1951(90)90244-3.

Lastras G., Canals M., Urgeles R., Hughes-Clarke J.E. \& Acosta J. (2004). - Shallow slides and pockmark swarms in the Eivissa channel, western Mediterranean sea. - Sedimentology, 51, 837-850.

Le Douaran S., Burrus J. \& Avedik F. (1984). - Deep structure of the northwestern Mediterranean basin: results of a two ship seismic survey. - Mar. Geol., 55, 325-345.

LEPRETRE A. (2012). - Contraintes par imagerie sismique pénétrante sur l'évolution d'une marge cénozoïque réactivée en compression (cas de la marge algérienne, secteur de Tipaza). - Thèse, université de Bretagne Occidentale, 236pp.

Lepretre A., Klingelhoefer F., Graindorge D., Schnurle P., Beslier M.O., Yelles K., Deverchère J. \& Bracene R. (2013). - Multiphased tectonic evolution of the Central Algerian margin from combined wide-angle and reflection seismic data of Tipaza Algeria. - J. Geophys. Res., 118, 3899-3916.

Lofi J., Deverchère J., Gorini C., Gaullier V., Gillet H., Guennoc P., Loncke L., Maillard A., Sage F. \& Thinon I. (2011). - Atlas of the Messinian salinity crisis markers in the Mediterranean and Black Seas. - Mém. Soc. géol. Fr., n.s., 179, and World Geological Map Commission, 72 pp.

LONERGAN L. \& White N. (1997). - Origin of the Betic-Rif mountain belt. Tectonics, 16 (3), 504-522.

Lüdmann T., Wiggershaus S., Betzler C. \& Hübscher C. (2011). - Southwest Mallorca island: A cool-water carbonate margin dominated by drift deposition associated with giant mass wasting. - Mar. Geol., 307-310, 73-87.

Ludwig W.J., NAFe J.E. \& Drake C.L. (1970). - Seismic refraction. In : A E. Maxwell, Ed., The sea. - Wiley-Interscience, New York, Vol. 4., 53-84.

Maillard A. \& Mauffret A. (1993). - Structure et volcanisme dans la fosse de Valence (Méditerranéen Nord-Occidentale). - Bull. Soc. géol. Fr., 164, 365-383.

MAillard A. \& MAuffret A. (1999). - Crustal structure and riftogenesis of the Valencia trough (northwestern Mediterranean sea). - Basin Res., 11, 357-379.

Maillard A. \& Mauffret A. (2011). - Valencia through. In Lofi et al., Eds, Atlas of the Messinian salinity crisis markers in the Mediterranean and Black Seas. - Mém. Soc. géol. Fr., n.s., 179 and World Geological Map Commission, $72 \mathrm{pp}$.

Maillard A. \& MAuffret A. (2013). - Structure and present-day compression in the offshore area between Alicante and Ibiza island (eastern Iberian margin). - Tectonophysics, 591, 116-130

Maillard A., Mauffret A., Watts A.B., Torné M., Pascal G., Buhl P. \& PineT B. (1992). - Tertiary sedimentary history and structure of the Valencia trough (western Mediterranean). - Tectonophysics, 203, 57-76.

Maillard A., Driussi O., Lofi J., Briais A., Chanier F., Hübscher H. \& GAullier V. (2014). - Record of the Messinian Salinity Crisis in the SW Mallorca area (Balearic promontory, Spain). - Mar Geol., doi: 10.1016/j.margeo.2014.10.001

Malinverno A. \& Ryan W.B. (1986). - Extension in the Tyrrhenian sea and shortening in the Apennines as a result of arc migration driven by sinking of the lithosphere. - Tectonics, 5, 227-245.

Marti J., Mitjavila J., Roca E. \& Aparicio A. (1992). - Cenozoic magmatism of the Valencia trough (western Mediterranean): relationship between structural evolution and volcanism. Tectonophysics, 203, 145-165.
Mascle J., Mascle G., Brosolo L., Camera L. \& Trevisan J. (2012). Geological and morphotectonic map of the Mediterranean domain. - CGMW Ed., Paris.

Mattauer M. (2007). - Comment est née la méditerranée? Hypothèses sur les rôles respectifs du rift oligocène ouest-européen et des grands courants asthénosphériques mio-pliocènes. - Bull. Soc. Hist. Nat., Toulouse, 143, 5-8.

Mauffret A., Maillard A., Pascal G., Torné M., Buhl P. \& Pinet B. (1992). - Long-listening multichannel seismic profiles in the Valencia trough (Valsis 2) and the Gulf of Lions (ECORS): a comparison. In: E. BANDA and P. SANTANACH, Eds., Geology and geophysics of the Valencia trough, western Mediterranean. Tectonophysics, 203, 285-304.

Mauffret A., Pascal G., Maillard A. \& Gorini C. (1995). - Tectonics and deep structure of the northwestern Mediterranean basin. Mar. Petrol. Geol., 12, 645-666.

Mauffret A., Frizon de Lamotte D., Lallemant S., Gorini C. \& MAILlaRD A. (2004). - E-W opening of the Algerian basin (western Mediterranean). - Terra Nova, 16 (5), 257-264.

Medaouri M., Deverchère J., Graindorge D., Bracene R., Badji R., Ouabadi A., Yelles K. \& Bendib F. (2014). - The transition from Alboran to Algerian basins (western Mediterranean sea): Chronostratigraphy, deep crustal structure and tectonic evolution at the rear of a narrow slab rollback system. - J. Geodyn., 77, 186-205. http://dx.doi.org/10.1016/j.jog.2014.01.003.

Michard A., Negro F., Saddiqi S., Bouybaouene M.L., Chalouan A., Montigny R. \& Goffé B. (2006). - Pressure-time-temperature constraints on the Maghrebide mountain building: evidence from the Rif-Betic transect (Morocco, Spain), Algerian correlations, and geodynamic implications. - C.R. Géosciences, 338, 92-114.

Nocquet J.-M. \& CALAIS E. (2003). - Crustal velocity field of western Europe from permanent GPS array solutions, 1996-2001. - Geosphys. J. Int., 154, 72-88.

Ochoa D., Sierro F., Lofi J., Maillard A., Driussi O. \& Flores J.-A. (2014). - The onset of the Messinian salinity crisis along the offshore Betic range. - Geophys. Res. Abstr., EGU 2014, Id. 1826.

Parès J.M., Freeman R. \& Roca E. (1992). - Neogene structural development in the Valencia trough margins from palaeomagnetic data. Tectonophysics, 203, 111-124.

Pascal G.P., Torné M., Buhl P., Watts A.B. \& Mauffret A. (1992). Crustal and velocity structure of the Valencia trough (western Mediterranean), Part II. Detailed interpretation of five expanded spread profiles. - Tectonophysics, 203, 21-35.

PlatT J.P. \& VisSERS R.L.M. (1989). - Extensional collapse of thickened continental lithosphere: a working hypothesis for the Alboran sea and Gibraltar arc. - Geology, 17, 540-543.

Ramos-Guerrero E., Rodríguez-Perea A., Sàbat F. \& Serra-Kiel J. (1989). - Cenozoic tectonosedimentary evolution of Majorca island. - Geodin. Acta, 3 (1), 53-72

Rehault J.-P., Boillot G. \& Mauffret A. (1984). - The western Mediterranean basin geological evolution. - Mar. Geol., 55, 447-477.

Rivière M., Bellon H. \& Bonnot-Courtois C. (1981). - Aspects géochimiques et géochronologiques du volcanisme pyroclastique foré dans le golfe de Valence: site 123, DSDP, Leg 13, (Espagne). Mar. Petrol. Geol., 41, 295-307.

Roca E. (2001). - The northwest Mediterranean basin (Valencia trough, Gulf of Lions and Liguro-Provencal basins): structure and geodynamic evolution. In: P.A. ZIEGLER, W. CAVAZZA and A.F.H. Robertson, Eds., Peri-Tethys Memoir, IGCP 369, Peri Tethyan rift/wrench basins and passive margins. - Mem. Mus. Natl. Hist. Nat., Paris, 671-706.

Roca E. \& Guimera J. (1992). - The Neogene structure of the eastern Iberian margin 938: structural contraints on the crustal evolution of the Valencia trough (western Mediterranean). - Tectonophysics, 203, 203-218.

Rosenbaum G. \& Lister G.S. (2004). - Formation of arcuate orogenic belts in the western Mediterranean region. In: A.J. Susman \& A.B. WEIL, Eds, Orogenic curvature: integrating paleomagnetic and structural analyses. - Geol. Soc. Amer. Sp. Paper, 383, 41-51.

Rosenbaum G., Lister G.S. \& Duboz C. (2002). - Reconstruction of the tectonic evolution of the western Mediterranean since the Oligocene. In: G. Rosenbaum and G.S. Lister, Eds, Reconstruction of the evolution of the Alpine-Himalayan orogen. - J. Virt. Expl., 7, 107-130. 
RoYDEN L.H. (1993). - Evolution of retreating subduction boundaries formed during continental collision. - Tectonics, 12, 629-638.

Sabàt F., Roca E., Muñoz J.A., Vergés J., Santanach P., Sans M., MasaNA E., Estévez A. \& Santisteban C. (1997). - Role of extension and compression in the evolution of the eastern margin of Iberia: the ESCI-Valencia trough seismic profile. - Rev. Soc. Geol. España, 8, 431-448.

Sabàt F., Gelabert B., Rodriguez-Perea A. \& Giménez J. (2011). - Geological structure and evolution of Majorca: Implications for the origin of the western Mediterranean. - Tectonophysics, 510, 217-238

Sage F. Pontoise B., Mascle J., Basile C. \& Arnould L. (1997). - Crustal structure and ocean continent transition at marginal ridge: the Côte d'Ivoire-Ghana marginal ridge. - Geo-Mar. Lett., 17, 40-48.

Sanz De Galdeano C. (1990). - Geologic evolution of the Betic cordilleras in the western Mediterranean, Miocene to the Present. - Tectonophysics, 172, 107-119.

Schettino A. \& Turco E. (2006). - Plate kinematics of the western Mediterranean region during the Oligocene and Early Miocene. Geophys. J. Int., 166, 1398-1423.

Serpelloni E., Vannucci G., Pondrelli S., Argnani A., Casula G., AnZidei M., Baldi P. \& Gasperini P. (2007). - Kinematics of the western Africa-Eurasia plate boundary from focal mechanisms and GPS data. - Geophys. J. Int., 169, 3, 1180-1200, doi: 10.1111/j.1365-246X.2007.03367.x.

Spakman W. \& Wortel R. (2004). - A tomographic view on western Mediterranean geodynamics. In: W. CAVAZZA, F. RouRe, W. SPAKMAN, G. STAMPFLI and P. Ziegler, Eds, The TRANSMED Atlas. The Mediterranean region from crust to mantle. Geological and geophysical framework. - Episodes, 27, 31-52.

Speranza F., Villa I.M., Sagnotti L., Vidallorindo, F., Cosentino D., Cipollari P. \& Mattei M. (2002). - Age of the Corsica-Sardinia rotation and Liguro-Provençal basin spreading: new paleomagnetic and Ar/Ar evidence. - Tectonophysics, 347, 231-251.
TAPPONNIER P. (1977). - Evolution tectonique du système alpin en Méditerranée: poinçonnement et écrasement rigide-plastique. - Bull. Soc. géol. Fr., 7, XIX, 3, 437-460.

Torné M., Pascal G., Buhl P., Watts A.B. \& Mauffret A. (1992). Crustal and velocity structure of the Valencia trough (western Mediterranean), Part I. A combined refraction/wide angle reflection and near-vertical reflection study. - Tectonophysics, $\mathbf{2 0 3}$ $1-20$.

Van Hinsbergen D., Vissers R. \& Spakman W. (2014). - Origin and consequences of western Mediterranean subduction, rollback and slab segmentation. - Tectonics, (in press). Doi: 10.1002/2013TC003349.

Vergès J. \& SABÀT F. (1999). - Constraints on the Neogene Mediterranean kinematic evolution along a $1000 \mathrm{~km}$ transect from Iberia to Africa. In: B. Durand, L. Jolivet, F. Horvath and M. SÉranNe, Eds, The Mediterranean basins: Tertiary extension within the Alpine orogen. - Geol. Soc. London, Sp. Publ., 156, 63-80.

Vergès J. \& Fernandez M. (2012). - Tethys-Atlantic interaction along the Iberia-Africa plate boundary: the Betic-Rif orogenic system. Tectonophysics, 579, 144-172.

Vidal N., Gallart J. \& Danobeitia J.J. (1998). - A deep seismic transect from the NE Iberian peninsula to the western Mediterranean. Geophys. Res., 103, 12381-12396.

Wessel P. \& Sмith W.H.F. (1991). - Free software helps map and display data. - EOS Trans. Amer. Geophys. Un., 72 (41), 441-446.

Yelles-Chaouche A., Boudiaf A., Duellit H. \& Bracene R. (2006). La tectonique active de la région nord-algérienne. - C.R. Geoscience, 338, 126-139.

Zeck H.P. \& Whitehouse M.J. (1999). - Hercynian, Pan-African, Proterozoic and Archean ion microprobe zircon ages for a Betic-Rif core complex, Alpine belt, W Mediterranean - consequences for its P-T-t path. - Contrib. Mineral Petrol., 134, 134-139. 